\title{
LA IMAGEN DEL PODER NOBILIARIO EN CASTILLA. EL ARTE Y LAS ÓRDENES MILITARES EN EL TARDOGÓTICO ${ }^{1}$
}

\author{
THE REPRESENTATION OF NOBILIARY POWER IN CASTILE. \\ ART AND MILITARY ORDERS IN THE LOWER GOTHIC
}

\author{
Olga PÉREZ MonZÓN \\ Universidad Autónoma de Madrid
}

\begin{abstract}
Resumen: El presente artículo analiza un elenco de obras artísticas -capillas funerarias, espacios palatinos, objetos litúrgicos y libros miniados- realizadas durante el siglo XV bajo el patrocinio de maestres $\mathrm{y}$, comendadores pertenecientes a las Órdenes de Calatrava y Santiago. El estudio de las mismas permite apreciar cómo estas dignidades, vinculadas a instituciones religiosas y militares, manifestaron unas idénticas preocupaciones artísticas a las de la aristocracia laica del momento.
\end{abstract}

Palabras Clave: Poder; Representación; Orden de Calatrava; Orden de Santiago; Capilla funeraria; Palacio; Libro miniado; Tardogótico.

\begin{abstract}
This paper analyzes a series of masterpieces, such as funerary chapels, palatial spaces, liturgic objects and illuminated books produced during the 15th century, under the protection of the Calatrava and Santiago Orders Grand-Masters and Commanders. A detailed study of these masterpieces allows us to appreciate how these high dignities belonging to religious and military Orders had the same concernings as the laic aristocracy.
\end{abstract}

Key words: Power; Representation: Military Order of Calatrava; Military Order of Santiago; Funerary Chapels; Palaces; Illuminated books; Late Gothic.

\section{SUMARIO}

1. Ámbitos Fúnebres: 1.1. La iglesia-panteón de Calatrava la Nueva. 1.1.1. Capilla de Pedro Girón. 1.1.2. Capilla de Diego García de Castrillo. 1.2. La iglesia-panteón de la Orden de Santiago: Uclés. 1.2.1. Capilla de Álvaro de Luna.- 2. De palacios y casas maestrales.- 3. De libros y otras dádivas. 3.1. La Biblia de Alba y Luís González de Guzmán

Durante el siglo XV, importantes linajes nobiliarios alcanzaron las más altas cotas de poder y representación en el seno de las Órdenes Militares. Su actividad política-religiosa se completó con el patrocinio de obras artísticas convertidas en punto de referencia obligado en el estudio del tardo-gótico

\footnotetext{
${ }^{1}$ El presente artículo se enmarca en el proyecto de investigación Las relaciones de conflicto en sus prácticas representativas (la Corona de Castilla en su contexto europeo, siglos XIII-XV). Proyecto HUM2006-05233/HIST del Plan Nacional I+D+I del Ministerio de Educación y Ciencia.
} 
castellano. En el presente artículo, vamos a centrar nuestra atención en el ámbito funerario terminando con unas referencias generales sobre el espacio palatino y el encargo de libros miniados y objetos litúrgicos para poder ofrecer una visión global sobre las inquietudes artísticas de estas dignidades nobiliarias pertenecientes a las Órdenes Militares ${ }^{2}$.

\section{1. ÁMBITOS FÚNEBRES}

La piqueta y el tiempo han sido particularmente poco generosos con dos emblemáticos panteones vinculados a las Órdenes Militares: los conventos de Uclés (Cuenca) y Calatrava la Nueva (Ciudad Real). El primero, vinculado a la Orden de Santiago, cambió su epidermis medieval por una factura renacentista y barroca; mientras que el segundo, casa madre de la Orden homónima, se abandonó en los primeros años del siglo XIX debido a lo inhóspito de su geografía. Lo comentado otorga un peso específico a las fuentes documentales para evocar la fisonomía medieval de ambas construcciones ya que las dignidades santiaguistas y calatravas, como destacados miembros nobiliarios, en aras de su anhelada fama post-mortem concedieron una gran importancia a sus ámbitos fúnebres.

Ambas instituciones siguieron unas similares pautas sobre las costumbres funerarias. Los primeros que optaron por enterrarse en lugar sacro fueron los familiares de la Orden, miembros de la alta nobleza que al convertirse en generosos benefactores de estos edificios recibieron, como contrapartida, la facultad de inhumarse en sus recintos. En Uclés, el ejemplo más destacado fue el del infante don Manuel y su esposa doña Constanza que el 8 de enero de 1261, tras hacerse confreyres e familiares de la institución santiaguista, elegían su conventual conquense como ámbito de inhumación y establecían cuatro capellanías. El documento incluye la promesa del maestre Pelayo Pérez Correa de hacerles una capiella en Uclés y mantener quatro capellanes que canten y missas por vos e por vuestros defunctos por siempre jamás ${ }^{3}$. No sabemos con exactitud cómo se ejecutó este ofrecimiento maestral, al contar sólo con una referencia tardía, una visita de 1515 donde se citan al lado del altar mayor dos arcos de enterramiento para don Juan Manuel, su mujer y dos hijos suyos ${ }^{4}$. Del mismo modo, en Calatrava la Nueva conocemos los enterramientos del magnate leonés Rodrigo Fernández fallecido en 1246 y del infante Alfonso de Mesa, hermano de Fernando III. Documentos posteriores hablan del sepulcro nobiliar con el finado en posición yacente y

\footnotetext{
${ }^{2}$ Sobre la evolución interna experimentada por estas instituciones vid. E. RODRÍGUEZ-PICAVEA MATILLA El proceso de aristocratización de la orden de Calatrava (siglos XIII-XV), Hispania Sacra, LIX (2007).

${ }^{3}$ Archivo Histórico Nacional (AHN), Órdenes Militares (OOMM), carp. $339 \mathrm{n}^{\mathrm{o}} 13$. Pub. M. RIVERA GARRETAS, La Encomienda y el Priorato de Uclés en la Edad'Media 1174-1310, MadridBarcelona, 1985, pp. 420-421, doc. n ${ }^{\circ} 213$.

${ }^{4} \mathrm{AHN}$, OOMM, libro $1079 \mathrm{c}$, fol. 334. De momento, ignoramos si estas obras son el resultado de una referencia posterior o aluden a un plan inicial.
} 
arrimado a la pared, conforme al modus arcosolio. Nada queda de esta obra funeraria ${ }^{5}$.

El proceso de aristocratización experimentado en el seno de las Órdenes permite que, con probabilidad a finales del siglo XIII y con certeza en la siguiente centuria, los maestres puedan optar a estos privilegiados lugares de sepultura. Su elección fluctúa entre determinadas dependencias del claustro o el templo propiamente dicho.

La capilla de San Agustín del convento de Uclés, lugar de celebración de capítulos, se aderezaba con lápidas y bultos de maestres ${ }^{6}$. Su situación claustral enfatiza las similitudes con las salas capitulares de otras órdenes religiosas empleadas como cementerio de abades/as ${ }^{7}$. Otras dignidades maestrales optaron por el enterramiento en la iglesia donde, conforme al principio de jerarquización del espacio fúnebre estudiado por el profesor Bango $^{8}$, la cabecera constituye el espacio más reputado. La iglesia de Calatrava la Nueva ejemplifica este aserto con los ámbitos fúnebres de Pedro Girón y Gonzalo Núñez de Guzmán que, en palabras de un documento de 1666, son colaterales de la [capilla] mayor de nuestra iglesia 9 .

La asunción del maestrazgo a finales de la Edad Media por los Reyes Católicos supuso una mayor "democratización" de estos usos fúnebres. Al siglo $\mathrm{XV}$, corresponden los enterramientos en lugar sacro de comendadores mayores, priores o tesoreros que, según las circunstancias, construyeron un arcosolio, una tumba exenta o una capilla en el templo o en los claustros anejos $^{10}$. Los conjuntos de Uclés y Calatrava son un claro exponente de esta realidad.

${ }^{5}$ Para el conocimiento de estos sepulcros, hoy perdidos, son fundamentales las visitas y documentos relativos al conventual. Mención especial merece una visita de 1644 publicada por COTTA Y MÁRQUEZ DEL PRADO, Descripción del Sacro Convento y Castillo de Calatrava la Nueva, cabeza y cuna de esta Orden y Caballería y de sus rentas y cosas, "La Mancha", I n ${ }^{\circ} 2$ (1961), pp. 40-41. Esta descripción de mediados del siglo XVII fue publicada con anterioridad por V. CASTAÑEDA Y ALCOCER, Descripción del sacro convento de Calatrava la Nueva, "Boletín de la Real Academia de la Historia”, 28 (1928), pp. 402-443.

${ }^{6}$ Significativamente, el conjunto de san Marcos de León tiene en su claustro una capilla dedicada a san Agustín que atiende a la misma funcionalidad y la iglesia santiaguista de Tudía (Badajoz) tiene adosada a su cabecera un pequeño habitáculo dedicado a San Agustín empleado con sentido funerario. Vid. A. RUIZ MATEOS, O. PÉREZ MONZÓN y J. ESPINO NUÑO Architecture and power: the Seats of Priories of the Order of Santiago, "The Military Orders fighting for the faith and caring for the sick", Londres, 1994, pp. 302-309.

${ }^{7}$ Vid. I. BANGO TORVISO, El monasterio medieval, Madrid, 1990, pp. 46-47 y C. ABAD CASTRO, El pabellón de monjes, "Monjes y monasterios. El Cister en Castilla y León", Valladolid, 1998, pp. 189-195.

${ }^{8}$ I. BANGO TORVISO, El espacio para enterramientos privilegiados en la arquitectura medieval española, "Anuario del Departamento de Historia y Teoría del Arte", IV (1992), pp. 93-132.

${ }^{9} \mathrm{AHN}$, Archivo Judicial de Toledo (AJT), leg. 45.865, s/f.

${ }^{10} \mathrm{~A}$ lo apuntado, hemos de unir los cementerios de freires situados en el claustro; en Calatrava la Nueva, recibe el expresivo título de claustro de los mártires. 


\subsection{La iglesia-panteón de Calatrava la Nueva}

Durante el largo debate promovido desde finales del siglo XVIII sobre la conveniencia o no de trasladar a los conventuales de Calatrava la Nueva ${ }^{11}$, varias opiniones incidieron en su abrupta e inhóspita topografía ${ }^{12}$. Particularmente excesivo en sus comentarios fue el ministro Juan López Altamirano al afirmar que mi voto es que siendo la real voluntad de S.M. el que se traslade, no con la mayor, sino con la posible brevedad del horroroso, áspero e inaccesible sitio en que se halla constituido el sacro convento de Calatrava donde sólo se oye el aullido de las fieras, el ruido que resalta de los montes y cabernas a la sociedad y civilidad de la población de la villa de Almagro ${ }^{13}$. En términos parecidos, se expresaba un siglo antes el capellán del convento para justificar el deterioro del sagrario ${ }^{14}$. Ciertamente, para una mentalidad ilustrada adicta al progreso y la civilización, la situación aislada de Calatrava resultaba incomprensible. Los hechos no eran diferentes en el medievo, pero sí su valoración.

En origen, Calatrava fue un emplazamiento fronterizo; mas pasado el peligro militar, mantuvo su condición de edificio símbolo y anhelado ámbito de inhumación para las dignidades de la Orden ${ }^{15}$. Al entierro en la iglesia del hermano de Fernando III, sucedieron los sepulcros y capillas de diferentes

\footnotetext{
${ }^{11}$ Según la información recogida en el Expediente formado sobre la traslación del sacro convento de Calatrava a la villa de Almagro, el proyecto de traslación se remonta a la época de Felipe II que impulsó la redacción de una bula de Pío V en 1568 con este propósito (AHN, OOMM, leg. $\left.36501, n^{0} 1\right)$. Otros sucesos fueron especialmente dañinos para el conventual y avivaron la polémica sobre su emplazamiento como el fuerte huracán ocurrido en 1655, descrito minuciosamente en los textos, y los efectos del terremoto de Lisboa de 1755 que motivó el traslado temporal de la comunidad a Calzada de Calatrava. La documentación relativa a este último episodio de la vida del convento ha sido parcialmente publicada por M. CORCHADO Y SORIANO, Traslado y supresión del sacro convento de Calatrava,"Cuadernos de Estudios Manchegos", 5, II época (1974), pp. 205-271.

${ }^{12}$ Frente a éstas, los defensores de la pervivencia del conventual subrayaban su antigüedad, historia y la conservación en su interior de "suntuosos" sepulcros. En los siguientes términos, se expresaba el marqués de la Granja: «Es muy ciẹrto que la razón de antigüedad no es suficiente, ¿pero quién ha dicho, que sea esa sola la que estimula a la conservación del Sacro Convento? La antigüedad únicamente por sí, no es de gran momento, pero quando recae sobre un objeto único en su especie, arreglado enteramente a sus fines, y conservado siglos hace a costa de desvelos y gastos, sobre un objeto que es depósito de las memorias más venerables de la Orden, que se halla con todos los fondos necesarios para sostenerse, y que está en excelente estado, y sobre un objeto que es la admiración de quantos le ven, que solo su aspecto inspira dignidad y que encierra cẹnizas de Mártires Cristianos, de Héroes y hombre señalạdos en virtud y mérito que dejaron sus bienes y sus cuerpos para que se custodiasen en aquel preciso y determinado sitio, inscribiéndose sus nombres, sus armas, y su memoria en lápida y sepulcros suntuosos de mármol para elevar los corazones de sus descendientes, y perpetuas en sus familias señales indelebles de su nobleza quando la antigüedad recae sobre todo esto es una antigüedad que clama por su respeto por su conservación y por la justa gratitud de los hombres» (AHN, OOMM, leg. 36501, n ${ }^{\circ} 1$, s.f.). Nos parece de especial relevancia el énfasis otorgado al uso fúnebre de Calatrava.

${ }^{13} \mathrm{El}$ informe corresponde al año 1797 (AHN, OOMM, leg. 36501, s.f.).

${ }^{14}$ El 8 de agosto de 1659, el capellán expresaba su queja al rey como presidente de las órdenes: «El sagrario está indecente y peligroso hecho partes que cabe una mano y no tiene más aderezo que hacelle de nuevo y para que de presente he solicitado traer oficial que le repare y no lo he podido conseguir porque todos huyen de este desierto y no hay dinero para pagar a los artífices» (AHN, AJT, leg. 45.517, s.f.).

${ }^{15}$ El tratamiento pormenorizado de los enterramientos en Calatrava la Nueva en M.A. CORTÉS ARRESE, El espacio de la muerte y las Ordenes Militares, Cuenca, 1999 y E. RODRÍGUEZPICAVEA MATILla y O. PÉREZ MONZÓN, Mentalidad, cultura y representación del poder de la nobleza calatrava en la Castilla del siglo XV, "Hispania”, LXVI (2006), pp. 177-219.
} 
miembros de notables linajes nobiliarios ${ }^{16}$ como los Guzmán $^{17}$, Padilla ${ }^{18}$, Girón $^{19}$ y Castrillo ${ }^{20}$. Estos financiaron lápidas, sepulcros, retablos, alhajas e incluso ciclos de pintura mural ${ }^{21}$. Sin embargo, en Calatrava no sólo se acometieron empresas de carácter fúnebre ${ }^{22}$. Los Reyes Católicos, tras asumir el maestrazgo calatravo en 1489, patrocinaron unas interesantes reformas a las que nos referiremos posteriormente. A mediados del siglo XVII, se proyectaba la construcción de una sala de reliquias limítrofe al templo conforme a un boceto inédito conservado en el Archivo Histórico Nacional que, por lo

${ }^{16} \mathrm{Un}$ acercamiento global a estos linajes nobiliarios en el seno de la orden calatrava en E. RODRÍGUEZ-PICAVEA MATILLA, Linaje y poder en la Castilla Trastámara. El ejemplo de la Orden de Calatrava, Anuario de Estudios Medievales, 35/1 (2005), 91-130.

${ }^{17}$ La capilla de Gonzalo Núñez de Guzmán (1385-1404), en el ábside meridional, estaba adornada con escudos calatravos y los relativos a su linaje, pinturas murales y un sepulcro alabastrino que mantenía la tipología del yacente. Su sucesor, Luis González de Guzzmán colocó su lápida -de piedra negra, epitafio y escudos con calderas- en el centro de la capilla mayor.

${ }^{18}$ Debajo de la capilla mayor, estaban las lápidas con inscripciones y escudos de Fernando de Padilla y García López de Padilla $(\dagger 1489)$. El comendador mayor Gutierre de Padilla construyó una capilla, llamada la Grande, en el hastial del evangelio y su sucesor García de Padilla (15231542 ) adquịió el espacio que quedaba entre la capilla de Diego García de Castrillo y la sacristía. Su decoración le otorgó el sobrenombre de Capilla Dorada.

${ }^{19}$ Pedro Girón se enterró en la cabecera, como veremos en las siguientes páginas. Su hijo, Rodrigo Téllez Girón, no contó con un enterramiento acorde con el de los maestres del siglo XV al reposar sus restos en una caja pequeña de madera, cubierta con terciopelo negro. Esta caja permaneció sobre unas sillas de la capilla mayor hasta 1577, cuando fue trasladada a la capilla de su padre: «La caxa donde están los huesos del señor maestre don Rodrigo Girón está en la capilla mayor del convento a la parte de la epístola sobre unas sillas como de choro donde se sientan legos que oyen misa, quando fuemos tenía encima un paño pequeño de terciopelo negro, ya muy viejo y con mucho polvo que deve de ser el que dexaron quando se puso allí y después le pusieron un doser con cinco amitos de terciopelo los tres de carmesí y dos de verde. Ternán de largo quatro varas y media y de ancho tres e ya viejo. Este dizen que llevaron con el cuerpo y se rescató por veinte y cinco escudos. Y asy le ponen sobre la caxa de los huessos las fiestas principales syn hazer otra memoria mas de que quando se haze capítulo general siempre se acuerdan como los huessos de tan principal senor y maestre están tan indecentemente y se trata de que algunos cavalleros de la horden den quenta de ello a los señores de la casa de Giron para que se les faga capilla o den entierro conforme a su merescimiento y para sacar los huesos de allî es menester Ticencia del rey del consejo de hórdenes porque de otra manera no lo consintieron» (AHN, Nobleza, Osuna. leg. 41, n ${ }^{\circ} 12$ ).

${ }^{20} \mathrm{~A}$ la capilla de Diego García de Castrillo, comendador mayor de la Orden, dedicaremos las siguientes páginas. Rebasada la barrera cronológica de 1500 , tenemos la capilla fundada por Francisco de Bobadilla, comendador de Auñón, junto a la capilla de Nuestra Señora de los Mártires en Calatrava la Nueva. En ella se enterraron el obrero Juan de Burgos, Juan de Valdelomar, comendador de El Viso, y probablemente Pedro de Torquemada, comendador de Lagunarrota. Vid. COTTA Y MÁRQUEZ DEL PRADO, Descripción del Sacro Convento y Castillo de Calatrava la Nueva, p. 63.

${ }^{21}$ En 1794, Fernando Becerra, freire partidario del traslado del conventual reconoce esta realidad en clave peyorativa: «... las pinturas de alguna estimación que existen en el sacro convento son algunos cuạdros portátiles, y fáciles de conducir a cualquier parte: fuera de esto solo se mira una estrella o vidriera de cristal que tuvo en los tiempos pasados una pintura de algún mérito pero en el día solo existen algunos retazos de ella mezclados con otros sin pintura alguna cuyos remiendos hazen un objeto sumamente desagradable: lo demás de este ramo consiste en algunos barnizes bastos con que están manchadas las paredes de algunas capillas y nada más hay de pintura. En quanto a los sepulcros solo hay en la Iglesia dos o tres de algún mérito, pero son conducibles pues constan de piezas pequeñas pegadas con cal que se desprenden con suma facilidad. Lo demás en este ramo son algunas losas viejas en tierra fírme, con algunas inscripciones ilegibles, pero de una arquitectura tosca que no merezen la dicha de ser trasportadas..." (AHN, OOMM, leg. 76501, n ${ }^{\circ} 1$, s.f.).

${ }^{22}$ Los reparos no cesaron en el conventual. En 1545, el circuito de murallas recibió un especial aditamento (AHN, OOMM, leg. 42478, s.f.). y en 1776, los maestros Andrés Ruiz de la Serna y Jerónimo García, respectivamente vecinos de Daimiel y Ciudad Real, acometieron importantes obras de reforma que afectaron, especialmente, a las cubiertas de la iglesia, las capillas anejas y los cuatro paños del claustro (ÄHN, OOMM, leg. 6018, s.f. ). 
menos, constata la cuantía de los ornamentos custodiados en el conventual calatravo $^{23}$. Y en 1774, tras los efectos nocivos del terremoto de Lisboa, se levantó un impresionante conjunto habitacional cuyos planos -no catalogados- se conservan también en el Archivo Histórico Nacional ${ }^{24}$.

La prolongada cronología de estas actuaciones constata la preocupación constante por la reforma y mantenimiento del conventual; sin embargo, conviene señalar que no todas tuvieron la misma entidad. En Calatrava la Nueva, y en ello estriba también su particularidad, hubo obras notables que nos sitúan en las precisas coordenadas del valor representativo de este edificio $\mathrm{y}$, por tanto, de la publicitación dada a lo que allí ocurría. Centraremos nuestra atención en la iglesia para referirnos a las capillas de Pedro Girón y Diego García de Castrillo al representar con diferentes matices la imagen del poder nobiliario. La primera fue uno de los más suntuosos espacios fúnebres levantado en el tardogótico por reputados artífices del momento. La segunda corresponde a la fase del maestrazgo real, hecho que justifica su ornato y que hemos de vincular a las intervenciones puntuales y selectivas que los Reyes Católicos tuvieron en Calatrava ${ }^{25}$.

\subsubsection{Capilla de Pedro Girón}

Pedro Girón $(† 1466)$, despechado pretendiente de la reina Isabel y camarero mayor de los reyes, adquirió altas cotas de poder en el seno de la Orden calatrava ${ }^{26}$ y acumuló uno de los más importantes patrimonios nobiliarios de su tiempo con el que creó un mayorazgo para su hijo Alfonso Téllez Girón con el título de conde de Urueña, origen de la casa Osuna ${ }^{27}$. Tan ambicioso comportamiento se coteja en la entidad de sus empresas artísticas,

${ }^{23}$ AHN, AJT, leg. 45.865, s.f.

${ }^{24}$ Andrés Ruiz de la Sierra y Jerónimo García de Céspedes, alarifes vecinos de Daimiel y Ciudad Real, describen las condiciones de este habitáculo (AHN, OOMM, leg. 3651², n⿳0 8, s.f.).

${ }^{25}$ La capilla Castrillo, durante un tiempo, custodió el estandarte de la Orden que enarbolaban los maestres, en un gesto simbólico propio de la alta nobleza y familia real. Un documento de 1746 nos da información precisa de sus dimensiones y de las razones por las que estaba en la capilla: «... En una de las capillas de su iglesia mayor que se intitula de los señores Castrillos se a puesto pendiente y colocado al lado derecho de la altar della un estandarte antiguo de la horden de damasco blanco como de cinco cuartas poco más o menos de largo y de lo ancho como de una vara y por entrambos azes se alla grabada una cruz grande de damasco negro como la que usa mi nominada horden, el qual dicho estandarte siempre a estado colocado en dicha capilla y sitio según consta de las difiniziones de nuestra horden y otros instrumentos y por haverse caído en ocasión de estar en este sacro convento uno de los patronos de dicha capilla que fue el marqués de Villanueva de Duero, caballero profeso de dicha horden, ponerlo por lo maltratado que estaba y abiéndolo restituido se a buelto a poner en su lugar como ba referido» (AHN, Nobleza, Bornos, C. 825, D. 4, "Estandarte antiguo de la Orden de Calatrava en la capilla Castrillos del Sacro Convento").

${ }^{26}$ J. O'Callaghan, Don Pedro Girón, Master of the Order of Calatrava, 1445-1446, "Hispania", 21 (1961), pp. 342-392 (reimpresión en su libro The Spanish Military Order of

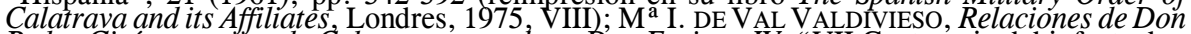
Pedro Girón, maestre de Calatrava, con el rey Don Enrique IV, "VII Centenario del infante don Fernando de la Cerda", Ciudad Real, 1976, pp. 159-170.

${ }^{27}$ Vid. F.J. AGUADO GONZÁLEZ, El ascenso de un linaje castellano en la segunda mitad del siglo XV: los Téllez Girón, condes de Urueña (el origen del señorío de Osuna) 2 vols., Madrid, 1991 ; A. FRANCO SILVA, Don Pedro Girón, fundador de la Casa de Osuna (1423-1466), "Osuna entre los tiempos medievales y modernos (siglos XIII-XVIII)", Sevilla, 1995, pp. 63-93. 
hoy desvirtuadas por la ruina y el deterioro que se ha cernido sobre ellas. Nos referimos al palacio maestral de Almagro y, de forma excepcional, a su capilla funeraria.

El maestre eligió como lugar de enterramiento el ábside norte de la iglesia de Calatrava la Nueva, un espacio ciertamente privilegiado que, en la actualidad, ofrece un pálido reflejo de su otrora magnificencia [figura $\left.\mathrm{n}^{\circ} 1\right]^{28}$.

Para su ejecución, Girón acudió a Hanequín de Bruselas, según se desprende de una cláusula de su testamento redactado el 28 de abril de 1466 en Villarrubia:

\begin{abstract}
...mando que mi cuerpo sea sepultado en el convento de mi horden en la forma e manera que las reglas e difiniçiones de aquella lo permiten e mandan. E que sea sepultado en la capilla que yo mandé fazer en la yglesia del dicho convento, la qual mando que se faga e acabe por la vía e manera que yo lo tengo hordenado e ygualado con maestro Haniquin, de que está razón en los libros de mi fazienda... Item mando que sean fechas mis honrras segund se acostunbran fazer a los maestres que antes de mi fueron e como mejor e más conplidamente se deuiere o pudiere fazer ${ }^{29}$.
\end{abstract}

La elección de Hanequín de Bruselas como el artífice de la capilla de Pedro Girón no debe de pasar desapercibida. Este artista flamenco llegó entre 1430 y 1435 al reino castellano acompañado de un equipo de arquitectos, entalladores y escultores, entre los que se encontraba su hermano Egas Cueman, llegando a ser maestro mayor de la catedral de Toledo ${ }^{30}$. Cuando Pedro Girón le encarga su capilla funeraria, el arquitecto se encuentra en el cenit de su carrera artística. El noble calatravo en su intento de representar su poder y memoria post mortem busca lo mejor entre lo que puede encontrarse en la Castilla del momento. La decisión indica hasta que punto Girón valoraba la fama y la transmisión de una cuidada imagen para la posteridad.

El maestre también buscó la magnificencia en el material elegido: el alabastro. Un documento de 1644 define la capilla como una obra de alabastro. A falta de estudios que arrojen claridad sobre este aspecto, pensamos que los visitadores emplearon el término con sentido metonímico al corresponder la utilización de este apreciado material a partes concretas del recinto fúnebre como la solería ${ }^{31}$, quizá un zócalo, el sepulcro propiamente

\footnotetext{
${ }^{28}$ Tratamos el tema de forma más sucinta en O. PÉREZ MONZÓn, Las manifestaciones artísticas como expresión del conflicto "La Monarquía como expresión del conflicto", director José Manuel Nieto Soria, Madrid, 2006, pp. 547 y ss.

${ }^{29}$ B. CASADo Quintanilla, Corona de Castilla: Documentos de la Orden de Calatrava pertenecientes a los tres últimos maestrazgos (1445-1489), Madrid, 1997, p. 296.

${ }^{30}$ Hanequín realizó en la catedral de Toledo obras de gran riqueza ornamental, participó en la girola de la catedral de Cuenca y, posiblemente, en el castillo de Escalona (J.M ${ }^{\mathrm{a}}$ DE AzĆ́RATE, El maestro Hanequin de Bruselas, "Archivo Español de Arte", XXI (1948), pp. 173188 y Arte gótico en España, Madrid, 1990, pp. 116-117).

${ }^{31}$ Según el texto mencionado, el suelo estaba cubierto de pequeñas losas blancas y negras (COTTA Y MÁRQUEZ, Descripción del Sacro Convento, p. 42).
} 
dicho y determinadas piezas litúrgicas como un tabernáculo de alabastro y una imagen de alabastro que está en su capilla ${ }^{32}$.

La simplicidad de este ornato de altar quedaba contrarrestada por la figuración de la vidriera de la ventana de la cabecera con la secuencia de la Deesis, las imágenes de san Andrés y san Bernardino - ligadas probablemente a la devoción de Girón- y escudos nobiliarios ${ }^{33}$. De este modo, se evitaba colocar en la capilla un retablo de mayores dimensiones que hubiese restado protagonismo al principal elemento de la capilla, el sepulcro alabastrino de Pedro Girón que además recibía la iluminación policroma de la vidriera, lo que debía generar efectos de gran belleza visual. Desgraciadamente, esta obra tumular ha desaparecido, mas por diversos textos inéditos conocemos ciertos detalles del mismo que nos llevan a considerarlo un hito importante en el desarrollo del monumento fúnebre tardo-gótico.

El túmulo, de formato rectangular y la representación del difunto como yacente ${ }^{34}$, se mantenía poco receptivo a las novedades iconográficas concretadas en la segunda mitad del siglo XV, léase el empleo de la pose orante en el difunto o la sustitución del animal acompañante por un paje/servidor que manifiesta en su actitud afligida la tristeza por el óbito ${ }^{35}$. La originalidad del cenotafio estribaba en la secuencia de las paredes con el cincelado de un oficio de exequias fúnebres, una procesión de freires calatravos y, en las esquinas, cuatro figuras angélicas sostenedoras de emblemas heráldicos de dos tercias de alto (lo que equivale a unos $60 \mathrm{cms})^{36}$. La medición de las mismas es importante por la comparación posterior que estableceremos con los cenotafios de Álvaro de Luna.

\footnotetext{
${ }^{32}$ Ambas piezas aparecen citadas en un inventario de 1495 (AHN, OOMM, leg. 6109, no 29, fol. 178).

${ }^{33}$ La descripción del vitral es el siguiente: « La claridad que tiene la capilla es por la parte del altar al oriente como el altar mayor del convento. Tiene una vidriera y en to alto un crucifixo con Nuestra Señora y San Juan a los lados y en lo más ancho de ella pintados en ella San Andrés a la mano derecha y San Bernardino a la yzquierda. Entre las cabeças destos sanctos un poco más alto que viene a estar al pie de la cruz, en la misma vedriera están las armas de los girones» (AHN, Nobleza, Osuna, leg. 41, n⿳⺈ 12). La misma heráldica lucía en las nervaduras de la bóveda donde campeaban ángeles de medio relieve con los escudos de los girones.

${ }^{34}$ En 1583 la capilla y el bulto del maestre estaban buenos e bien reparados (AHN, OOMM, leg. 42.436, Visitación al Sacro Convento, fol. 2 v.).

${ }^{35}$ Vid. J. YARZA LUACES, La imagen del rey y la imagen del noble en el siglo XV, "Realidad e imágenes de poder. España a fines de la Edạd Media”, coord. A. Rucquoi, Valladolid, 1988, pp. 285-286. La primera manifestación hispánica del modelo orante corresponde a la estatua de obispo Lope Barrientos, fechada a mediados del siglo XV. Se encarga de resumir las posturas sobre el particular C.J. ARA GIL, Fray Lope de Barrientos, "Comercio, mercado y economía en tiempos de la reina Isabel”, Valladolid, 2004, pp. 102-105.

${ }^{36} \mathrm{La}$ excepcionalidad de este sepulcro justifica que subrayemos los principales textos de información con los que contamos, la conocida visita de 1644 (COTTA Y MARQUEZ, Descripción del Sacro Convento, pp. 42-43) y una documentación inédita, sin datar cuyo contenido transcribimos a continuación: " A los lados del bulto en el sepulchro por la delantera que es a la cabeza están quatro bultos del mismo alabastro como de freiles religiosos con hábitos como quien haze officio para enterrar y por los lados del sepulcro bultos de caballeros con escudos que tienen de las manos yzquierdas con sus armas de cada uno. El primero comencando por la mano derecha tiene letras que dizen: don Fadrique de Acuña. Y el segundo: frey Gonzalo Cuello. Los demás aunque tienen sus escudos con armas que por ellas se puede entender quien herán no tienen las de su nombre y las armas, como estava oscuro no podria por ellas entender quienes heran y aun parescíanme diferentes de las que agora ordinariamente se leen» (AHN, Nobleza, Osuna, leg. 41, $\left.\mathrm{n}^{\mathrm{O}} 12\right)$.
} 
Hace unos años, José María de Azcárate ${ }^{37}$, basándose fundamentalmente en la conocida descripción de 1644, planteó las similitudes del cenotafio con la tumba de Felipe el Atrevido de la cartuja de Champmol por la bicromía de sus materiales -el sepulcro Girón tiene una basa y una lápida superior negras - y la procesión de cartujos plorantes que con diferentes gestos - unos leen, otros meditan con el rosario,...- aportan la nota dramática al acto ${ }^{38}$. El mismo historiador planteó la autoría de Egas Cueman, opinión que ha sido secundada por autores como Pérez Higuera ${ }^{39}$ o Domínguez Casas ${ }^{40}$ que, asimismo, mantienen la referencia del sepulcro francés. Desde nuestro punto de vista, ambos planteamientos son cuestionables. La aseveración sobre la autoría nos parece aventurada al no existir ningún documento que lo avale ni algún resto material del mismo. Tampoco llegamos a ver el valor referencial señalado por el profesor Azcárate al sepulcro de Champmol, máxime cuando podemos situar al sepulcro de Girón en las coordenadas del arte desarrollado en Castilla.

Las procesiones fúnebres, consideradas por Alfonso X en las Partidas como la demostración del respeto al monarca fallecido y por extensión a los nobles de la sociedad, fueron un tema recurrente en los túmulos desde el siglo XIII. A esta centuria, corresponde la tumba del infante don Felipe, hermano del rey Sabio, en Villálcazar de Sirga cuyas paredes se adornan con secuencias concretas dedicadas a las diferentes fases del duelo: plañideros, traslado del ataúd, luto de familiares y cabalgadura vacía del infante con el escudo invertido en señal de duelo ${ }^{41}$. El siglo XIV mantuvo esta tradición como ejemplifica la tumba de la abadesa Urraca de Cañas con una procesión de monjas cistercienses y las habituales profesionales del llanto ${ }^{42}$.

El cenotafio de Girón, según nuestra interpretación, participa de esa tradición con la metamorfosis que supone la sustitución de la comitiva anónima por otra de personajes reales. Según indican los documentos, los freires calatravos que conformaban el cortejo tenían sus armas privativas y unas cartelas donde figuraba su nombre ${ }^{43}$. Los visitadores transcriben, de

\footnotetext{
${ }^{37}$ Según Azcárate, el maestro Egas pudo intervenir también en las tumbas de los padres y abuelos đe Pedro Girón en la colegiata de Belmonte (AZCÁRATE, Arte gótico en España, p. 245).

${ }^{38} \mathrm{La}$ tumba de Champmol fue realizada entre 1384 y 1410 por los maestros Jean Marville, Claus Sluter y Claus de Werve. [S. JUGIE, Tombeau de Philippe le Hardi, "L'art à la court de Bourgogne, Le mécénat de Philippe leHardí et de Jean sans Peur (1364-1419)", París, 2004, pp. 223-225].

${ }^{39} \mathrm{El}$ foco toledano y su entorno, "Actas del Congreso Internacional sobre Gil Siloe y la escultura de su época", Burgos, 2001, p. 272.

${ }^{40}$ Arte y etiqueta de los Reyes Católicos. Artistas, residencias, jardines y bosques, Madrid, 1993 , p. 39.

${ }^{41}$ Sobre este monumento tumular, resultan de obligada consulta los artículos de J. YARZA LUACES, Despesas fazen los omnes de muchas guisas en soterrar a sus muertos, "Fragmentos", 2 (1985), pp. 4-19 y C.J. ARA GIL, Monjes y fralles en la iconografía de los sepulcros románicos y góticos, "Vida y muerte en el monasterio románico", Aguilar de Campo, 2004, pp. 161-200.

${ }^{42} \mathrm{~F}$. ABAD LEÓN, Real Monasterio de Cañas. Nueve siglos de fidelidad, Logroño, 1984, pp. $135-140$.

${ }^{43}$ Las descripciones del monumento tumular insisten en la individualidad de los miembros del cortejo y en su colocación en nichos independientes, en ningún caso aluden a su gesto doliente.
} 
forma concreta, los de Fadrique de Acuña y Gonzalo de Cuello. El dato es revelador porque hemos podido cotejar que Acuña y Cuello fueron coetáneos a Girón desempeñando respectivamente los cargos de comendadores de Zorita y Alcolea, Benavente y Almadén ${ }^{44}$. De tal forma, la comitiva se convierte en la mejor rúbrica visual de la férrea autoridad con la que Pedro Girón dirigió a la institución calatrava durante 20 años. Bajo este prisma, adquiere una especial intensidad la loa escrita en su epitafio:

Aquí yace el Muy Magnifico y muy Virtuosso Senor el noble don $\mathrm{P}^{\circ}$ Jirón, Maestre de la cavalleria de la orden de calatrava, Camarero Mayor del Rey de Castilla y León y del su Consexo, el qual, en veynte años que fue Maestre, en mucha prosperidad esta orden rigió, defendió y acrecentó en muy gran pujança. desta pres ${ }^{\text {te }}$. vida falleçió a dos días de Mayo Anno del Señor M.CCCC.LX.VI ${ }^{45}$.

Pedro Girón se ocupó además de dotar con magnificencia su ajuar litúrgico ${ }^{46}$. De forma concreta, los textos mencionan varias vestimentas completas - llamativa debía de ser la de seda negra con una rica cenefa y las armas de los girones-, un frontal de Ras con temas de la Pasión y un paño luctuoso de cinco piernas para encima de la sepultura ${ }^{47}$. Por comparación con otras piezas, de las que hablaremos en las páginas siguientes, y el recurso habitual empleado en la capilla a la decoración heráldica pensamos que estos útiles debían recibir ese aderezo. Todos esos objetos se explayaban en las ceremonias in memoriam convirtiendo la capilla en un ámbito de ostentación nobiliar.

El maestre también dispuso la celebración de sus funerales. Los freires del convento de Calatrava la Nueva recibieron 10.000 maravedís de juro de heredad situados por salvado en la ciudad de Córdoba, a cambio de oraciones, la celebración de una misa diaria en la capilla y el responso sobre

${ }^{44}$ CASADO QUinTANILla, Corona de Castilla: Documentos de la Orden de Calatrava, $\mathrm{n}^{\mathrm{0}} 13$, $19,20,25,26$ y 29.

${ }^{45}$ AHN, Nobleza, Osuna, leg. 41, $\mathrm{n}^{\circ} 12$.

${ }^{46}$ En una cláusula testamentaria encarga la realización de los siguientes ornamentos: «Item mando que se fagan para la dicha mi capilla tres casullas: la vna, de tapete negro, e sirua los lunes; e la otra, de seda blanca, que sirua los sábados; e la otra, de tapete verde, e sirva los otros días de la semana. E así mesmo que sea de lienço e otras cosas que fueren menester para dalmátyças e otros enderesços de las dichas capillas e para la dicha capilla, lo qual se faga a disposición de los dichos mis testamentarios. Iten mando treynta marcos de la mi plata que yo traygo de contino para que se fagan dos cálizes e dos candeleros e una cruz e vn par de binageras para la dicha capilla, lo qual todo se faga a disposición de los dichos mis testamentarios» (Casado Quintanilla, Corona de Castilla: Documentos de la Orden de Calatrava, $\mathrm{n}^{\mathrm{O}} 21$, pp. 296-298. El testamento de Pedro Girón había sido publicado anteriormente por F. Uhagón, Ordenes militares, "Discursos leídos ante la Real Academia de la Historia", IX (1898), pp 84-94; A. VINA BRITO, Testamento de don Pedro Girón, "Anuario de Estudios Medievales", 19 (1989), pp. 493-505). Inventarios posteriores constatan la realización de estas piezas: «Tiené mas un cálice dorado e un par de candeleros dorados e un par de ampollas doradas señaladas de la horden de de sus armas e una crus...» (AHN, OOMM, leg. 6109, fol. 178).

${ }^{47}$ «Tiene otra vestimenta la dicha capilla de seda negra con su çenefa rica e sus asmáticas del mesmo paño con sus cordones negros pardillos con todos sus aderecos de amitos e alvas e estolas e manípulos e pedro pico en las alvas del mesmo paño e en las asmáticas de azul e escudos de sus armas en ellos e un frontal de carmesí colorado con estaños de argenteria de plata e otro frontal de ras de la pasyón e un paño negro de terçiopelo negro de çinco piernas para ençima su sepultura...» (AHN, OOMM, leg. 6109, $\mathrm{n}^{\mathrm{o}} 29^{\prime}$, fol 178). 
la sepultura ${ }^{48}$. Significativamente, un letrero en la entrada de la capilla recordaba esta manda ${ }^{49}$. Del mismo modo, en una cláusula testamentaria, encargaba que el día de su entierro se dijeran 60 misas en su memoria recompensando a cada oficiante con una limosna de diez maravedís ${ }^{50}$, la celebración de dos vigilias anuales y misas segund e tan conplidamente como se suele dezir por los otros maestres, e que se digan más dosçientas misas en los logares que entendieren mis testamentarios. Al parecer, todo se hizo siguiendo las instrucciones del maestre Girón, ya que el 1 de junio de 1466, el capítulo de la Orden de Calatrava reunido en Almagro comunicó al concejo de Murcia que fue leuado su cuerpo a la sepultura con aquella honor e reuerençia que podimos ${ }^{51}$.

\subsubsection{Capilla de Diego García de Castrillo}

El siguiente ámbito del que nos vamos a ocupar es el de Diego García de Castrillo. Castrillo fue maestresala de los Reyes Católicos, activo militar en la guerra de Granada y comendador mayor ya que, desde 1489, los Reyes Católicos ostentaban el maestrazgo de la Orden de Calatrava. La nueva situación de la institución se refleja en sus empresas artísticas ${ }^{52}$.

\footnotetext{
${ }^{48}$ Las misas debían decirse de la siguiente manera: «los días de lunes una misa cantada de requiem con su responso; e los días de los sábados otra misa cantada del ofiçio de nuestra señora la Virgen María en quien yo tengo deuoçión; e los otros días, cada día, vna misa rezada...encargando a los dichos freyles çerca de esto sus conçiençias». Más adelante el maestre calatravo indicaba que al prior y freires de su convento de Calatrava les entregaran 30.000 maravedís para asegurar el rezo por su alma. Vid. RODRÍGUEZ-PICAVEA Y PÉREZ MONZÓN, Mentalidad, poder y representacion.

${ }^{49}$ «En una piedra de la puerta de arco de la capilla dentro de la rexa de hierro que tiene están unas letras esculpidas que dizen "Dízese en esta capilla del maestre don Pedro Girón una misa cada día dexo a este convento diez mill maravedís de juro". Encima de estas letras esta una tablita con una papel escripto de (ileg.) esta capilla hizo el señor maestre don Pedro Girón dótola en diez mill maravedís de renta situados sobre las alcávalas de los salvados de la fruta de Córdoba. Las quales se traspasaron y se cobran en las alcávalas de las carnicerias de Ciudad Real. Dízensele tres misas cada semana» (AHN, Nobleza, Osuna, leg. $41, n^{\circ} 12$ ).

${ }^{50} \mathrm{~A}$ ello había que sumar los cinco treintanarios que debían decirse por su alma en los monasterios de San Francisco de Ubeda, la Sisla de Toledo, La Cabrera, San Francisco de Peñafiel y Olmedilla, además de los 15 treintenarios por sus difuntos padres que dejaba comisionados en la iglesia de la villa de Belmonte. Vid. RODRÍGUEZ-PICAVEA Y PÉREZ MONZÓN, Mentalidad, poder y representación.

${ }^{51}$ Publ. C. TORRES SUÁREZ, Don Rodrigo Téllez Girón, maestre de Calatrava, "Anuario de Estudios Medievales" 11 (1981), 775-792 $\mathrm{n}^{\circ}$ 2; CASADO QUINTANILlA, Corona de Castilla: Documentos de la Orden de Calatrava, $\mathrm{n}^{\circ} 23$.

${ }^{52}$ En 1632, sus descendientes Luisa de Castrillo y Guzmán y Luis y Pedro Castrillo Fajardo reformaron la capilla, la dotaron de 1000 reales de renta perpetua y añadieron una inscripción encomiástica que glosaba el cursus honorum del benefactor de templo con la cita a la antiguedad del linaje leones de Castrillo, al carácter valeroso del comendador mayor, a su eficacia en la lucha contra los musulmanes y a su promoción artística: «A la buena memoria del sr. don frey Diego García de Castrillo, caballero leonés de la casa de Castrillo tan antigua y fuerte que. por tradición de aquella tierra se cree que resistió al orgullo y poder de los moros, el qual fue tan valeroso que llegó a ser Comendador Maior y Administrador del Maestrazgo de la orden de Calatrava. en paz y en guerra en lugar del último maestre. Mereçió dignamente la gracia de los $\mathrm{S}^{\text {es }}$. Reyes Cathólicos D. Fernando y $\mathrm{D}^{\mathrm{a}}$ Isabel así porque con la auctoridad que tenía en su orden dispuso mas suavemente la incorporación del maestrazgo de Calatrava en la corona Real, como porque habiendo sido su maestresala y capitán de trescientas lanças les asistió treinta i cinco años continuos sin soltar las armas de las manos en las guerras contra los moros asta que el día que sujeto el Reyno de Granada se halló a poner los pendones de Santiago y Real en la Torre del Homenaje y de la Alambra. Dando en todas ocasiones exemplo raro de valor y prudencia a los
} 
Castrillo sufragó el coro del templo de Calatrava la Nueva. No queda nada de esta estructura. Sabemos que era de madera, de su carácter policromo y de la existencia de una notoria cartela que contenía una amplia cita sobre la guerra de Granada con referencias a su duración y la colocación del emblema real en la torre del homenaje de la Alhambra ${ }^{53}$. Nos preguntamos si ese extenso texto se materializó en alguna iconografía del acontecimiento bélico, como ocurre en la sillería baja del coro de la catedral de Toledo; aunque de momento sólo podemos asegurar que en los estalos se cincelaron las armas reales y las de Castrillo como acertado preámbulo de la figuración de la bóveda.

La dignidad calatrava también construyó una capilla funeraria en la nave del evangelio, a los pies del templo; de ella restan sólo los muros al haber desaparecido su bóveda de cerramiento y su ornato interior ${ }^{54}\left[\right.$ figura $^{\mathrm{o}}$ 2]. Tales pérdidas otorgan un valor añadido a unos preciosos dibujos inéditos que hemos encontrado en el Archivo de la Nobleza de Toledo relativos a un arreglo efectuado en la capilla en $1632^{55}$.

suios y de terror y admiración a los enemigos, como en aquella batalla de las faldas de la sierra del Madroño tan memorable que desde su tiempo quedó para memoria de la posteridad escrita en la de todos por aber sido como Increíble el estrago que hico en la morisma él solo, siendo Alcayde de los Alcazares de Eçixa, por su mano, abriendo primero que acometiesse cortado las piẹrnas a su caballo para animạr y no parecer a su gente superior más que en la grandeza de aquel animo que tanto se aventajó siempre en la exaltación de la Fe y nombre de los christianos. y en el rendimiento de la perfidia y fuerças de los moros. Fue singular benefactor de su orden y de sus caballeros cuyo sacro convento enrriqueció con la fábrica đel coro que se acabó año de 1492 y el de 1493 con esta capilla que quisso fuesse fiel depósito de su cuerpo asta la Resurrección universal y para el de sus herederos, permitiendo que solamente se enterrase en ella en la forma que él don frey Ramiro Nuñez de Guzmán, clavero de Calatrava, por lo mucho que le amó y estimo. Adonde se vé el estandarte de la orden en testimonio de la auctoridad y poder de maestre con que en su vacante la administró. Sus herederos y sucesores renovaron y dotaron esta capilla, año de 1632» (AHN, Nobleza, Bornos, C. 826, D. 4).

${ }^{53} \mathrm{El}$ contenido exacto de la misma era el siguiente: «Esta obra deste coro mandó facer don Diego García de Castrillo comendador mayor de la Orden de Calatrava, mestresala y capitán del Rey e Reyna nuestros señores. El qual residió treinta y cinco años en la guerra de los moros fasta que el Rey e Reyna nuestros señores acabaron la conquista del Reyno de Granada, mandaron poner la cruz y el pendón de Santiago y el pendón real encima del omenage de la Àlambra de Granada. Acabose año del nacimiento de nuestro señor de mil e cuatrocientos y noventa y dos años» (AHN, Bornos, C. 826, D. 4).

${ }^{54} \mathrm{La}$ elevada altura del conventual propició continuos daños en el templo. En 1544, Enrique Egas y Pedro Machuca de Granada aconsejaban hacer 15 pilares de ladrillo para sujetar el muro a la parte de las capillas. Todas las capillas, inclusive la de Castrillo, eran de reducidas dimensiones, altura proporcionada y solían cubrirse con bóvedas de crucería.

${ }^{55} \mathrm{El}$ boceto se acompaña de una explicación detallada que transcribimos a continuación: « ... en la puerta de la capilla está una reja de palo pintada a colores y en el umbral della embebido en la mesma viga está un escudo cuarteado que es éste -dibujo del escudo Castrillo- El mismo escudo está en el arco de la puerta de la capilla. Dentro de la capilla en medio de la bóbeda en el cimborio están las armas del emperador [sic] según y como van copiadas. Los leones del cuartel derecho alto y hizquierdo bajo pardos. Los castillos de oro, el campo rojo = Las varras de los otros dos cuarteles cinco de oro en campo rojo águilas negras campo de oro coronas de oro y la corona del águila del escudo, aunque se le a caydo, y la caveza y cola della es de oro = Deste escudo salen los arcos según y como van copiados a los quatro rincones de la capilla, de cada uno dellos al lienzo sale un escudo que son cuatro. El de la cabecera del águila es de cruz de Calatrava en campo de plata y travas de oro y asimismo el que corresponde al lienzo bajo = El que cay al lienzo del lado derecho del águíla es de cruz de Alcántará en campo de plata travas de oro y asimismo el que corresponde al hizquierdo. A cada rincón va a rematar un arco y remata en medio y en el remate de cada uno ay un escudo como este de arriba que está en la puerta de la capilla con las mismas armas, campo y colores. Asimismo en el lienzo que estaba frente de la puerta de la capilla ay otro escudo hecho de yeso suelto y colgado en un clavo con las mismas armas y del otro calvo está colgado un estandarte de damasco blanco o plateado con la cruz de Calatrava que entonzes era negra. El sepulcro de mano derecha que es el de don Ramiro de 
El primero de esos dibujos se refiere a los sepulcros de Castrillo y de su clavero Ramiro Núñez de Guzmán que ocupaban el centro de la capilla ${ }^{56}$ [figura $\mathrm{n}^{0} 3$ ]. El dibujo funciona como un desplegable de tal forma que los emblemas heráldicos corresponden a las cuatro paredes de los monumentos tumulares $^{57}$; a la vez, las armerías contienen algunos objetos de los campos o textos donde se describe su figuración aportando interesantes datos sobre su policromía. Las siluetas figurativas reproducen las tapas o lápidas de cerramiento con los finados en posición yacente con el perro simbólico a los pies. Los yacentes representan las señas de identidad esenciales de la institución a la que pertenecen: la religión y la guerra, a través del hábito y la espada.

Los monumentos tumulares ${ }^{58}$, de tres varas de largo y dos de ancho, tenían una cartela que precisaba su cronología $-1493-59$ y estaban realizados

Guzmán según allí consta de su misma inscripción en este lado primero que es el que tiene de su [ileg.] en la madera del sepulcro embebido ay de medio a medio del un escudo grande como de la copiado de las armas de los Guzmanes: dos calderas ajedrezadas a colores rojo y oro en los remates de las asas adentro y fuera de la caldera como va copiada seis cabezas de sierpes de oro, el campo del escudo azul. A1 lado derecho deste escudo está otro con cruz de Calatrava en campo de plata y travas de oro. Al otro lado que es izquierdo otra con cruz de Alcántara, campo de plata, travas de oro = A la cavecera deste sepulcro como va copiado está otro escudo que tiene por armas seis piñas que parezen negras en campo de plata = y el mismo escudo está a los pies del dicho sepulcro. Todos con sus colores como va decclarado aunque antiguos. El sepulcro de la mano dẹrecha que está pegado al dicho y de una misma heçhurạ y pintura que según dize su inscripción es de don Diego García de Castrillo. Tiene al lado izquierdo que es el que se descubre un escudo grande con las armas arriba copiadas de torres y lunas y mesas en la misma forma que están en la puerta y arços y al lado derecho otro escudo en correspondencia del otro sepulcro de cruz de Calatrava y al izquierdo de Alcántara con los mismos campos y colores = A la cabecera deste sepulcro está el mismo escudo que el de Alcántara con los mismos campos y colores $=\mathrm{A}$ la cabecera de este sepulcro está el mismo escudo que al lado y a los pies del mismo. En las sillas que la hospedería tiene en la iglesia corresponden a las del coro y todas son de una hechura y mano. Estan en cada banda dos escudos, el uno es de las armas del emperador [sic] de la suerte que van copiadas en la bóbeda y vajo dẹste escudo está otro con las armas desta capilla según y como están en la puerta y arcos. Las mismas armas he visto en muchas çasullas de colonia muy antiguas que el convento tiene en un cajón antiguo de la sacristía que oy viven de notable hechura y asimimismo dos o tres ternos de damasco blanco y verde las tienen de que algunas vezes usa la sacristía en fiestas donde su misma antigüedad disculpa la rịsa que causa el modo con que están cortados y dispuestos y quando no hubiera otra executoria la capellanía sino esta casulla y ornamentos para su antiguedad le vastavan fuera de las tradiciones que tiene $=$ Sustentan los sepulcros doce leones de madera dorados» (AHN, Nobleza, Bornos, C. 826, D. 4).

${ }^{56} \mathrm{El}$ epitafio del sepulcro del clavero justifica esta insólita circunstancia por afectọ. Tampoco sería ilógico pensar en las continuas cesiones del comendador Castrillo al ser el primero en su cargo enterrado en Calatrava; además su amado clavero era un miembro del linaje Guzmán.

${ }^{57} \mathrm{El}$ citado boceto se acompaña de la siguiente leyenda:

[sepulcro de don Ramiro de Guzmán] Pared larga (tres encasamentos): cruz de Calatrava en campo de plata y travas de oro-dos calderos con estos ajedrezados y colores rojo y oro. Las cabezas de las sierpes de oro. Paredes estrechas: Escudo de seis piñas negras, campo de plata. [sepulcro de Diego García de Castrillo]. Pared larga (tres encasamentos): cruz de Alcántara, campo de plata, travas de oro - escudo Castrillo. Primer campo: cinco torres de oro, campo rojo. Segundo campo: tres leones de plata campo azul/ dos mesas de oro campo verde. Tercer campo: tres leones de plata campo azull dos mesas de oro campo verde. Cuarto campo: cinco torres de oro, campo rojo.

${ }^{58}$ Los sepulcros eran ornamentales ya que, en medio de la capilla, había una bóveda de dos varas y medio de largo, vara y quarta de ancho donde se encontraban los huesos del comendador en un ataúd. Debajo del altar, había otra bóveda que nunca llegó a cobijar restos humanos (AHN, Nobleza, Bornos, C. 826, D. 5).

${ }^{59} \mathrm{La}$ inscripción exacta rezaba de la siguiente manera: «Aquí iace don Diego García de Castrillo, comendador mayor de la Orden de Calatrava, capitan y maestresala de los muy esclarecidos y muy poderossos el rey don Fernando y la reyna doña Isabel nuestros señores el qual mandó facer esta capilla y estos enterramientos la qual obra se acabó a catorce días del mes 
en madera policromada, material más económico que el alabastro empleado por el maestre Girón ${ }^{60}$. Tipológicamente son conservadores en su formato paralelípedo, yacente con atavío correspondiente, colocación de la espada en posición de parada, perro simbólico a los pies y escudos heráldicos envolventes. Con probabilidad, eran estructuras exentas. Así se desprende de su sujeción sobre doce leones pintados de oro - seis cada uno- y la cita contenida en otro documento donde se habla de una diferente altura entre ambos $^{61}$. Una mayor altura debía priorizar la tumba Castrillo y, probablemente, también el aderezo de la almohada, tradicional símbolo de preferencia.

El otro dibujo encontrado corresponde a la bóveda de cerramiento de la capilla, hoy perdida [figura $\mathrm{n}^{\mathbf{0}}$ 4]. La armería nobiliar figuraba en los cuatro arranques de los nervios de la bóveda ${ }^{62}$ y la cruz calatrava se exhibía en los puntos centrales de las paredes, mientras que la clave de la bóveda lucía ostentosa un escudo real. Es factible presuponer que sus dimensiones están magnificadas en el boceto, aunque su tamaño no era despreciable. Los visitadores hablan de más de una vara de longitud, lo que equivale aproximadamente a un metro ${ }^{63}$. Todo además tenía su correspondiente policromía resaltando el dorado del águila ${ }^{64}$.

El fundador estableció memorias y aniversarios por su alma donde se desarrollaban espectaculares escenografías in memoriam con repique de campanas, haceros encendidos e incensado de los paños fúnebres que cubrían

de noviembre año del naçimiento de nuestro Señor de mil y quatroçientos y noventa y tres» (AHN, Nobleza, Bornos, C. 826, D. 4).

${ }^{60}$ La policromía resultaba fundamental en estos monumentos: « dos túmulos de tres varas de largo poco más o menos, y de ancho dos varas con dos figuras de natural encima con mantos de coro, de bulto, encarnados los rostros y colorados los vestidos con sus cruces de Calatrava y en el túmulo en la frente principal tres escudos uno en medio pintado de oro y azul y dos, uno a un lado y otro a otro con una cruz de Calatrava el otro de Alcantara y alrededor de estos escudos en el friso de festones de oro por orla en campo de oro y avaxo un banco de jaspe de colores. Tiene mas por las frentes de los lados dos escudos uno en cada lado de plata, el campo y. armarios negros con sus festones por orla y desta misma suerte está el otro bulto que en los dos tienen diez escudos» (AHN, Nobleza, Bornos, C. 826, D. 5).

${ }^{61}$ «... en la capilla baxa donde ay dos sepulcros, en el más alto dize.... el letrero del otro sepulcro dize...» (AHN, Nobleza, Osuna, leg. 41, $\mathrm{n}^{\mathrm{O}}$ 12).

${ }^{62} \mathrm{La}$ armería nobiliar también figuraba en la entrada pared de entrada «-encima de la puerta un arco y un escudo de piedra-», en la verja de madera que acotaba el espacio «-un escudo de festones a los lados de diversos colores con su celada con plumas-, la vidriera, el retablo y diferentes ornamentos» (AHN, Nobleza, Bornos, c. 826, D.5).

${ }^{63}$ Agustín de Perola Espínola, pintor de Almagro, en la tasación de las obras de la capillas que realizo el 14 de octubre de 1633 dice: «Tiene la bóbeda de dentro de la capilla en la clave de en medio un escudo de armas de una vara de la fundacion dorado y colorado y un águila que lo abraca de pintura» (AHN, Nobleza, Bornos, c. 826, D.5).

${ }^{64} \mathrm{Las}$ fuentes transmiten alguna incongruencia. El dibujo incluye el escudo de los reyes católicos sin granada -incorrectamente identificado en una parte del texto con el del emperadormientras que la descripción de 1644 hace explícita relación a ésta. Otorgamos mayor veracidad a esta fuente ya que su inclusión se adecua perfectamente a la data de 1493 . 
los monumentos tumulares ${ }^{65}$. La capilla se aditaba con un retablo con temas heráldicos y una imagen doliente de Cristo afín a la estética tardogótica ${ }^{66}$.

$$
* * *
$$

La visión comparada de ambos ámbitos fúnebres resulta particularmente instructiva. Pedro Girón buscó la magnificencia en su capilla funeraria tanto en los materiales empleados como en la autoría seleccionada. En la arquitectura, acudió al maestro mayor de la catedral de Toledo, uno de los más afamados del tardogótico castellano y, en esos momentos, a la vanguardia estética. Todavía no conocemos la identidad del escultor del sepulcro cuyas particularidades iconográficas hemos resaltado. Los paralelismos con el cenotafio de Álvaro de Luna quizá sean indicativos de una misma autoría; de momento, importa destacar que actuó como modelo del cenotafio de Fernando de Córdoba contratado por Alonso de Covarrubias en $1555^{67}$, lo que nos habla de una obra "conocida" y "valorada".

La capilla Castrillo visualiza una nueva fase en el seno de las Órdenes Militares. Que las armerías particulares del comendador mayor cedan el protagonismo a las armas regias tiene el mismo significado -incluso más evidente- que las intervenciones realizadas por Isabel y Fernando en el conventual calatravo. Los monarcas, inmediatamente tras asumir el maestrazgo, colocaron escudos regios monumentales en el refectorio y en la sala de huéspedes de la llamada Casa de Pavones ${ }^{68}$. En el comedor, situado en el ala meridional del claustro, se realizó en la techumbre un trabajo del arte romano con racimos de oro, filacterias y una gruesa maroma de oro y azul con su letrero $^{69}$. La apostilla última debía responder a un friso epigráfico de

\footnotetext{
${ }^{65} \mathrm{El}$ documento corresponde a 1634 pero juzgamos que se mantiene el mismo ritual que en los años de fundación de la capilla: «el dicho aniversario fue una misa cantada con diácono y sudiácono y asistencia de todo el convento en la capilla mayor donde estava su paño de terciopelo con la cruz de la orden por túmulo como es costumbre no ubo hachas para todos los hacheros... Todos los aniversarios solemnes los celebra de una manera que es una vigilia y misa cantada con ministros y un paño en medio de la capilla de terciopelo con la cruz de la orden en las quatro esquinas quatro hacheros con sus hachas encendidas y mientras dura el oficio clamorean las campanas y un religioso está siempre incensando el dicho paño o túmulo y al fin de la misa se dice un responso cantado con gravedad» (AHN, Nobleza, Bornos, C. 826, D. 6).

${ }^{66}$ En la tasaciọ́n de 1633 se dice: « Sobre el altar un retablo de pinturas con quatro colunas y su banco y cornisa con su remate y en lo alto un escudo de quatro terzios con una cruz de Calatrava con sus travas y con su cartela y en la caja donde esta el Santo Cristo de la coluna por de dentro de... y estrellas de oro» (AHN, Nobleza, Bornos, c. 826, D. 5).

${ }^{67} \mathrm{~V}$. GARCíA REY, El famoso arquitecto Alonso de Covarrubias, “Arquitectura”, 1927, p. 416.

${ }^{68}$ Vid. J. Espino NuÑo, Obras de los Reyes Católicos en el Sacro Convento de Calatrava la Nueva, "El arte español en épocas de transición", I, Madrid, 1994, pp. 309-314.

${ }^{69} \mathrm{La}$ visita al convento de Calatrava de 1495 describe en los siguientes términos el refectorio: «... vymos el refitorio enlusydo e solado asy todo de ladrillo raspado e hechas en el muy buenas ventanas grandes labradas de cuchillo e otras algo menores con sus vedrieras en que está la Salutación y el cruçifixo e otras imágenes y están en el dicho refitorio XXXVI rasymos e XXXVI filiteras de oro y una maroma tan grande como el braco de oro e azul que lo anda todo alrededor e una grada grande que ésta de orden debe estar en los refitorios, hecha de sus azulejos y tres escudos de talla con las armas reales de sus altezas e hecho un facistor grande en la pared muy bueno para leer labrado de cuchillo y la puerta principal muy honrrada y grande labrada asymesmo de cuchillo mejor que todo lo otro y toda la obra della pyntada de oro e azul con las dichas armas» (AHN, OOMM, leg. 6109, fol. 171v).
} 
propaganda regia que se completaba con tres escudos hechos de talla de las armas reales ${ }^{70}$. Los diferentes habitáculos de la casa de los Pavones tenían un similar aderezo heráldico, en un número mayor, e igualmente un friso a lo romano debajo de los aliceres de la techumbre ${ }^{71}$. El porqué de esta "inminente" actuación real - su cronología oscila entre 1489 y 1495- obedece al interés regio por visualizar, con presteza, a los freires quiénes eran sus nuevos dirigentes e, igual que en la iglesia de San Juan de los Reyes (Toledo), se acudió como símbolo de potestad a la reiteración de motivos heráldicos. De forma expresa, el documento cita el tamaño de un estado de ombre de los escudos de las paredes del refectorio, lo que equivale a armerías de casi dos metros de altura ${ }^{72}$. Los lugares elegidos por los monarcas no deben pasar desapercibidos. Visitas posteriores citan el refectorio como una de las piezas más destacadas del convento; mientras que la casa de huéspedes está en la órbita de los diversos aposentamientos reales construidos por los Reyes en monasterios, castillos o palacios ${ }^{73}$. La estancia física de los monarcas en Calatrava parece que fue breve, mas sus símbolos reemplazaron su autoritas; precisamente esa autoritas regia es la que proclamaba la bóveda de la capilla Castrillo.

\subsection{La iglesia-panteón de la Orden de Santiago: Uclés}

Si Calatrava fue el edificio símbolo de la Orden homónima, el conventual conquense de Uclés fue la principal casa santiaguista en el reino de Castilla.

La donación de la fortaleza fronteriza por Alfonso VIII y Leonor de Plantagenet fue objeto de una miniatura en el llamado Tumbo Menor de Castilla o Libro de Privilegios de la Orden de Santiago ${ }^{74}$. La ilustración

\footnotetext{
${ }^{70} \mathrm{AHN}$, OOMM, leg. 6109, fol $261 \mathrm{v}$.

${ }^{71}$ Según la citada visita de 1495, el aposentamiento de huéspedes era un edificio de dos pisos. El inferior tenía salas de carácter económico-doméstico y el superior varias cámaras de función residencial .Este era su estado tras la obra real: " primeramente ha hecho enlucir e blanquear la sala prinçipal del dicho aposentamiento de los pavones e pyntar la madera y está heçha una muy buena chimenea francesa a la parte del çierzo y tres camaras con sus çaquicamis muy bien pyntados, soladas y enlusydas ... buenas puertas e cerraduras y los arcos dellas labrados de cuchillo todas ellas con las armas reales e pyntadas asymesmo la madera del corredor según que la otra y toda la dicha sala e corredor con una çinta pyntada de lo romano baxo de los alizeres... y la puerta de la entrada engrandeçida y blanqueada con las armas reales y todas las dichas puertas de la dicha sala e cámaras con las dichas armas reales» (AHN, OOMM, leg. 6109, fol. 171).

${ }^{72}$ También se buscó la magnificencia en el repertorio formal elegido y, sobre todo, en la estética a lo romano. La cita es particularmente interesante dada la temprana cronología del friso, lo que podría significar el trabajo de un artista avezado en las nuevas modas estéticas.

${ }^{73}$ Un estudio detallado de los mismos en R. DOMÍngUEZ CASAS, Arte y etiqueta de los Reyes Católicos. Artistas, residencias, jardines y bosques, Madrid, 1993, pp. 253-310.

${ }^{74} \mathrm{El}$ estudio de la misma en O. PÉREZ MONZÓN, Iconografía y poder real en Castilla: las imágenes de Alfonso VII", "Anuario del Departamento de Historia y Teoría del Arte", XIV (2002), pp. 19-41.
} 
reproduce un hecho ocurrido en $1174^{75}$ desde la perspectiva del siglo XIII ${ }^{76}$ y es importante remarcar ese lapsus cronológico porque las cosas habían cambiado notablemente para la institución santiaguista: embrionaria en el momento de la dádiva y con un patrimonio y estatus consolidado en la siguiente centuria.

Nada es azaroso en la imagen donde apreciamos un evidente interés en la identificación de los protagonistas y del hecho representado. Los monarcas, desde un mismo sitial, sujetan los hilos de un sello de gran tamaño que, a modo de las improntas empleadas en los documentos oficiales, actúa de elemento de validación del texto escrito a continuación, la comentada donación de Uclés, estableciendo un hábil juego visual entre el texto y la imagen. La identidad regia se subraya a través de los atributos ligados a su dignidad - nimbo y perspectiva jerárquica - , las cartelas colocadas sobre sus cabezas y la inscripción que circunvala el citado sello - REGIS CASTELLA SIGILLUM A-. Paralelamente, se personaliza al receptor de la donación, el maestre Pedro Fernández, y el objeto de la misma, una fortaleza con un pendón farpado elevado sobre la torre del homenaje donde figura la imagen ecuestre de Santiago invicto o militar ${ }^{77}$ enarbolando el arma justiciera de cuya fisonomía deriva la espada-cruz que adorna la vestimenta de los caballeros santiaguistas $^{78}$.

Interesa destacar que es la única ilustración del citado manuscrito.

El Tumbo Menor de Castilla entronca con la tradición de los Cartularios -Tumbo de Tumbo A, el Libro de las Estampas o el Tumbo de Toxos Outos - donde se incluyen miniaturas regias de modus mayestático para revalidar la entidad de sus donaciones y confeccionar objetos de gran belleza formal que recordaban la generosidad de los reyes predecesores y actuaba como estímulo de futuras dádivas ${ }^{79}$. La Orden de Santiago empleó este recurso primando la opción de Uclés, su principal sede en el reino de Castilla y su

\footnotetext{
${ }^{75}$ En el último tercio del siglo XII, Uclés era una villa de frontera dominada por el castillo de origen almohade unido a la población por un recinto amurallado. Vid. M. RIVERA GARRETAS, $L a$ encomienda, el priorato y la villa de Uclés en la Edad Media. Formación de un señorío de la Orden de Santiago, Madrid-Barcelona, 1985, pp. 34-38.

${ }^{76} \mathrm{La}$ mayor parte de los autores consideran que la miniatura corresponde a la primera mitad del siglo XIII: A. SICART La iconografía de Santiago ecuestre en la Edad Media, "Compostellanum" "27 (1982), p. 31; E. FERNÁNDEZ GONZÁLEZ, Iconografia y leyenda del pendón de Baeza. "Medievo Hispano. Estudios in memoriam del prof. Derek W. Lomas", Madrid, 1995 p. 148; PÉREZ MONZÓN, Iconografía y poder real en Castilla, p. 41.

${ }^{77}$ Sobre la iconografía del santo jacobeo vid. N. CABRILlANA CIEZAR, Santiago matamoros, historia e imagen, Málaga, 1999, pp. 30-33.

${ }^{78}$ Según A. SICART es la representación más antigua de Santiago con el caballo a paso lento que, en su concepción, rememora la ceremoniosa entrada del emperador victorioso llamada Adventus [La iconografia de Santiago ecuestre en la Edad Media, “Compostellanum”, 27 (1982),
p. 31].

${ }^{79}$ El Tumbo de Santiago (1129-ca.1255) fue ideado por el arzobispo Gélmirez para prestigiar la sede compostelana (E. FERNÁNDEZ GONZÁLEZ, Tumbo A, pp. 122-123); el Libro de las Estampas (ca. 1200) recoge las donaciones de siete reyes y una condesa a la sede legionense $(\mathrm{F}$. GALVAN FREILE, Libro de Estampas, p. 124) y el Tumbo de Toxos Outos (finales del siglo XIII) las relativas al cenobio gallego homónimo (J.GAITE PASTOR y O. PÉREZ MONZON, Tumbos de Toxos Outos, pp. 126-127). Todas las fichas en "Maravillas de la España Medieval. Tesoro sagrado y monarquía", León, 2000.
} 
posesión más emblemática, lo que propició que en no pocos documentos la Orden y sus freires fueran conocidos por la denominación de la fortaleza ${ }^{80}$.

A principios del siglo XIII, Uclés fue residencia prioral ${ }^{81} \mathrm{y}$, una vez alejado el peligro musulmán, la fortaleza se aderezó con un soberbio conjunto conventual de organización claustral en torno a la iglesia de Santiago que las principales dignidades santiaguistas eligieron como ámbito de inhumación. La drástica reforma emprendida en el conjunto a partir del siglo XVI promovida más por un "deseo de modernidad" que de "necesidad" otorga un gran protagonismo a las fuentes documentales para evocar el pasado medieval de Uclés ${ }^{82}$.

La capilla de San Agustín, situada en torno al claustro, tuvo un marcado uso funerario. La visita de 1494 menciona la sepultura de çiertos maestres y la presencia de bultos de yeso muy antiguos ${ }^{83}$. Es factible pensar que éstos correspondieran a maestres - de identidad desconocida - y que, conforme a un uso bastante extendido, fuesen almas de maderas preparadas para su cubrición policroma. La documentación no precisa estos datos, de momento sólo podemos establecer ciertos vínculos con lo ocurrido en las casas santiaguistas de San Marcos de León y Tudía (Badajoz) donde existieron sendas capillas dedicadas a San Agustín empleadas como lugares de sepultura de maestres ${ }^{84} \mathrm{y}$, en el caso del convento legionense, como sala capitular. La misma función asumió el habitáculo de Uclés tras el mandato de los citados visitadores de 1494 de enterrar los huesos, poner poyos alrededor para que allí se tenga capítulo y un letrero con el nombre de los maestres ${ }^{85}$. La intención subyacente de esta cartela, igual que en las salas de linajes nobiliarias o las galerías de reyes palatinas, era la de perpetuar la memoria santiaguista a través de sus principales representantes que, como hemos visto, eran enterrados en esta sala.

Con el tiempo, se alinearon varias capillas fúnebres en el hastial del evangelio de la iglesia, circunstancia que consolidó su carácter de espacio

${ }^{80} \mathrm{La}$ Orden consolidó su población con el fuero entregado por el maestre en 1179 por orden de Alfonso VIII. Este monarca, en su testamento de 1204, dejó claro que Uclés era lâ segunda fortaleza del reino. Vid. J. GoNZÁLEZ, Repoblación de Castilla la Nueva, I, Madrid, 1975-1976, pp. 272-274. p. 54 .

${ }_{54}^{81}$. Quintero AtAURI, Uclés, antigua residencia de la Orden de Santiago, Madrid, 1904,

${ }^{82}$ En el siglo XVI, diferentes circunstancias entre las que se incluye una buena coyuntura económica, animaron a las autoriḍades santiaguistas en 1525 a pedir la total reforma de Uclés e incluso sugerir un cambio de ubicación. Los afamados maestros de geometría Antón Egas y Alonso de Covarrubias participaron en el peritaje realizado, resultando su testimonio excepcional para conocer el estado real de la sede santiaguista. Finalmente, prevaleció el tradicional emplazamiento de Uclés y en 1529 se iniciaron las obras que terminaron en la centuria siguiente (AHN, OOMM, leg. 22.444). La fábrica medieval desapareció y, con ella, gran parte de sus monumentos tumulares.

${ }^{83} \mathrm{AHN}$, OOMM, leg. 1067c, fol. 107 v.

${ }^{84}$ La capilla de San Agustín de San Marcos, situada en torno al claustro, cobijó el sepulcro del maestre Pedro Fernández y la de Tudía, abierta a la iglesia, los de Gonzalo Mejía y Fernando Ozores. El monasterio pacense también custodió los huesos de Lorenzo Suárez Figueroa.

${ }^{85} \mathrm{AHN}$, OOMM, leg. $1067 \mathrm{c}$, fol. $107 \mathrm{v}$. Realmente, pensamos que el mandato revalidaba de facto una situación que ya existía. 
fúnebre. La principal fue la del maestre Rodrigo Manrique, comendador de Segura y conde de Paredes. El ámbito fúnebre estaba centralizado por una tumba de alabastro con bulto funerario y epitafio alrededor de la tapa sepulcral señalando sus victorias militares y la fecha de su fallecimiento $(1476)^{86}$. Estos cursus honorum epigráficos de carácter laudatorio fueron un elemento común en los monumentos tumulares tardogóticos, como apreciamos por citar dos ejemplos significativos vinculados a la Orden, en las tumbas del maestre Álvaro de Luna y del caballero Martín Vázquez de Arce, el célebre Doncel de Sigüenza. Poco más sabemos de este sepulcro, al que otorgamos una cierta calidad estética y que, desde los primeros años del siglo XVI, figuraba en el centro del presbiterio. El abandono de la capilla Paredes ${ }^{87}$, en el lado del evangelio, coincide con su empleo como escenario de las tomas de posesión santiaguistas documentándose tres sillas destinadas a este cometido en su recinto $^{88}$. Pensamos que estos usos podían verse entorpecidos por el monumento tumular procediéndose a su traslado a la cabecera del templo, ámbito preferente que prestigiaba aún más a un importante benefactor del conventual $^{89}$. Así ocurrió en San Marcos de León donde, en 1503, los visitadores ordenaban labrar un nuevo bulto de piedra del maestre Pedro Fernández -el antiguo se había roto al caerse al suelo baxo- con sus escudos y letreros porque esta memoria no perezca y colocarlo en el centro de la capilla de San Agustín ${ }^{90}$.

Otras dignidades santiaguistas eligieron el templo como ámbito fúnebre $^{91}$. Las capillas de Juan Hurtado de Mendoza y los priores Juan de Velasco y Hernando de Santoyo, junto con la comentada del maestre Manrique, se alineaban en el hastial del evangelio, el único espacio disponible debido a la situación meridional del claustro ${ }^{92}$. Todas corresponden al siglo $\mathrm{XV}$, se cubren con bóvedas de crucería o techumbres de madera y se aderezan con retablos, imágenes, alhajas y sus correspondientes bultos funerarios ${ }^{93}$.

\footnotetext{
${ }^{86} \mathrm{AHN}$, OOMM, libro 10c, fol. $453 \mathrm{v}$. fol. 5 ).

${ }^{87} \mathrm{La}$ capilla tenía una bóveda de cinco claves como cerramiento (AHN, OOMM, libro 1086c,

${ }^{88} \mathrm{AHN}$, OOMM, libro 1086c, fol. 5. Es plausible, que éstas coincidan con las de madera entallada de buena obra para uso del maestre y priores que, la visita de 1494, sitúa en la nave del templo (AHN, OOMM, libro 1067c, fol. 2).

${ }^{89}$ Los órganos del coro llevaban su rúbrica heráldica: « ... órganos pequeños bien obrados que el conde don Rodrigo Manrique maestre de la dicha horden, dio a la dicha iglesia» (AHN, OOMM, libro $1063 \mathrm{c}$, fol. 3 ).

${ }^{90} \mathrm{AHN}$, OOMM, libro $1093 \mathrm{c}$, fol. 278.

${ }^{91}$ En el claustro, además de numerosas lápidas de caballeros santiaguistas, figuraban la comentada capilla de los maestres viejos o capilla de San Agustín y los enterramientos de Alonso y Juan Díaz Coronado (AHN, OOMM, libro $1067 \mathrm{c}$, fol. 108; libro $1079 \mathrm{c}$, fol. $335 \mathrm{v}$; libro 1084 c, fol. 408; libro $1086 \mathrm{c}$, fol. 5). Ambos fueron priores de Uclés de 1389 a 1428 y de 1428 a 1472 respectivamente (GARRIDO HORCAJADA, Priores santiaguistas, p. 74).

${ }^{92} \mathrm{AHN}$, OOMM, libro 1067c, fol. 107; libro 1084c, fols. 407v-408; libro 1086c, fol. 5. Datos biográficos de estos personajes en A. GARRIDO HORCAJADA, Priores santiaguistas de Uclés, Uclés, 1982, pp. 75-86.

${ }^{93}$ La capilla Mendoza tenía una bóveda de crucería simple de una clave y un retablo dedicado a la Pasión y Nuestra Señora del Rosario. La de Juan de Velasco, una bóveda de terceletes de nueve claves y un retablo de San Miguel. L̇a de Hernando de Santoyo una techumbre de madera con sus vigas pintadas y un retablo de la Concepción, trasladado a mediados del siglo XVI a la
} 


\subsubsection{Capilla de Álvaro de Luna}

Álvaro de Luna (c. 1390-1435), maestre de la Orden de Santiago, no eligió un edificio de la Orden como lugar de inhumación, sino la catedral de Toledo. Nos parece fundamental incluir en este trabajo una referencia sintética a este reputado ámbito fúnebre por ser, a nuestro juicio, la expresión más acabada del poder maestral.

Conviene recordar que el poderoso valido de Juan II de Castilla, hijo bastardo de linaje aragonés, ostentó los títulos de conde de San Esteban, Condestable de Castilla y Maestre de la Orden de Santiago. Su excesivo personalismo, afianzado por su victoria contra los nazaríes en La Higueruela (1431) y los infantes de Aragón (1430 y 1445), le granjeó el odio y recelo de la aristocracia castellana y especialmente del príncipe heredero Enrique y determinó su caída en desgracia ${ }^{94}$. Juan II firmó su sentencia de muerte en 1453.

Etelvina Fernández ha trazado la compleja personalidad del condestable ${ }^{95}$. Fue un hombre de acción, un digno literato autor del Libro de las claras e virtuosas mugeres ${ }^{96}$, un cultivador de los usos cortesanos y un notable promotor artístico como ejemplifican la magnificencia de su residencia civil -palacio de Escalona- y su ámbito fúnebre - capilla de la catedral de Toledo-. Además, don Álvaro fue el protagonista de varios textos literarios, lo que es un indicio categórico de su preeminencia en la política castellana del siglo XV. En este contexto, entendemos que se arrogase iniciativas más propiamente relacionadas con la figura regia.

Don Álvaro tuvo su propia Crónica ${ }^{97}$. El texto participa del tono elogioso y lisonjero característico del género, de tal forma, se describe su espacio fúnebre como - la más notable, rica e maravillosa capilla e enterramiento suyo que en las Españas, e aun en la mayor parte del mundo, se pudiese hallar- y se enuncia el capítulo dedicado a su ajusticiamiento por de la muerte del mejor caballero que en todas las Españas ovo en su tiempo, e mayor señor sin corona, el buen Maestre de Santiago. Lo llamativo, no obstante, es la propia existencia de la Crónica apropiándose de un privilegio

sacristía (AHN,OOMM, libro 1086c, fol. 5).

${ }^{94}$ Se han ocupado monográficamente de esta figura J,M. CALDERÓN ORTEGA, Álvaro de Luna: riqueza y poder en la Castilla del siglo XV, Madrid, 1998 e I. PASTOR BODMER, Grandeza y tragedia de un valido. La muerte de don Alvaro de Luna, Madrid, 1992.

${ }^{95}$ Don Álvaro de Luna, Condestable de Castilla y Maestre de Santiago: hombre de su tiempo y promotor de las artes, "La nobleza peninsular en la Edad Media", León, 1999, pp. 135-170.

${ }^{96}$ J.M. FRADEJAS RUEDA, Libro de las virtuosas e claras mugeres, "Diccionario Filológico de Literatura Medieval Española. Textos y transmisión", coord. C. ALVAR y J.M. LUCÍA MEGÍAS, Madrid, 2002, pp. 188-191.

${ }^{97}$ Crónica de don Álvaro de Luna, Condestable de Castilla, Maestre de Santiago, ed. de J. MATA CARRIAZO, Madrid, 1940. La problemática de esta Crónica en F GOMEZ REDONDO, Crónica de Alvaro de Luna, "Diccionario Filológico de Literatura medieval española", pp. 293296. La Crónica fue publicada en Milán en 1545 por un bisnieto del antiguo condestable de Castilla para reivindicar la figura del noble. 
en un principio restringido a la figura regia y, al final del medievo, vinculado a los personajes políticos más relevantes de la época ${ }^{98}$.

La biografía de don Álvaro aparece glosada en otros textos poéticos contemporáneos. Juan de Mena, en palabras de Carla de Nigris, lo convierte en el héroe de su célebre poema El laberinto de la Fortuna (1444). El Condestable es el protagonista único del círculo de Saturno:

$¡ O$, tú, Providencia!, declara de nuevo/ quién es aquel cavallero que veo,/ que mucho en el cuerpo paresçe Tideo/ e en el consejo Nestor el longevo/... Este cavalga sobre la Fortuna/ e doma su cuello con ásperas riendas.../ ¿cómo, indiscreto, y tú non conoces/ al condestable Álvaro de Luna? ${ }^{9}$.

Los nombres mitológicos permiten al poeta definir al Maestre como un sabio y poderoso gobernante. El tono encomiástico se acrecienta en las siguientes coplas donde se considera al Condestable como el audaz doblegador de la Fortuna:

Agora', repuse, 'conosco mejor/ aquel cuyo ánimo, virtud e nombre/ tantas de partes le fazen de ombre/ quantas estado le da de señor; las quales le fazen ser meresçedor;/ e fruto de mano de nuestro grant rey,/ e clara experiencia de su firme ley,/ e de la Fortuna jamás vençedor'100.

El protagonismo del noble coexiste con la defensa, no exenta de crítica positiva, del ideal monárquico de Juan II y de la exaltación patriótica de Castilla y de su hegemonía peninsular ${ }^{101}$. Verdaderamente, Las Trescientas de Mena dan la medida del poder adquirido por don Álvaro y de lo que representó en la política castellana. El poema, además, aporta una información de interés artístico sobre la que volveremos más adelante.

Años más tarde, la pluma de Jorge Manrique evocó el trágico final del Maestre. El poeta dedica una estrofa de sus célebres Coplas por la muerte de su padre (1477) a rememorar su ajusticiamiento público visto como paradigma de la fugacidad de las cosas terrenas ${ }^{102}$. Unos años antes las circunstancias habían sido muy distintas para el Maestre.

1430, tras la expulsión de los infantes de Aragón de Castilla, fue un año especialmente significativo para el Condestable. El 23 de mayo Juan II

${ }^{98}$ Una panorámica global del género cronístico y biográfico en la Baja Edad Media y el análisis de las circunstancias que explican su éxito en J.M. NIETO SORIA, La cultura, "La época medieval: Iglesia y cultura”, J.M. NIETO SORIA e I. SANZ SANCHO, Madrid, 2002, pp. 412-418.

${ }^{99} \mathrm{~J}$. DE MENA, Laberinto de la Fortuna y otros poemas, ed. de C. DE NIGRIS, estudio preliminar de G. SERÉS, Barcelona, 1994, coplas 233 y 235, pp. 159-160. El séptimo círculo, el saturnino, es el único que no aparece dividido en la rueda del presente y del pasado.

${ }^{100}$ Mena, Laberinto de la Fortuna, copla 236, pp. 160-161. Según Nigris, la defensa a la política del noble resulta incontestable sobre todo al coincidir la terminación del texto en el exilio del privado (Prólogo, p. CLVII).

${ }^{101}$ Á. Gómez Moreno, Juan de Mena, "Diccionario Filológico", p. 671.

102 «Pues aquel grand Condestable/ maestre que conocimos/ tan privado, non cumple que dél se hable, / mas sôlo cómo lo vimos/ degollado..." (J. MANRIQUE, Coplas, "Obra completa”, dirigida y prologada por A. CoRTINA, Madrid, 1977, p. 125). 
firmó una carta de merced para la administración del maestrazgo de Santiago ${ }^{103}$ - cargo revalidado de facto en $1445-$. El 15 de agosto firmaba con el conde de Benavente las capitulaciones matrimoniales con su hija Juana de Pimentel ${ }^{104}$, lo que suponía el enlace con la más rancia nobleza castellana. Y el 18 de abril, el arzobispo de Toledo autorizaba al Condestable a ser inhumado en la catedral de Toledo emulando la decisión anterior de los monarcas Enrique II o Sancho IV ${ }^{105}$. La elección del maestre, clara mimesis de su biografía, supone la aminoración del convento santiaguista de Uclés, al que otorga piezas de uso litúrgico, frente a un ámbito urbano y de connotación regia. Hablamos de fama post mortem como expresa el propio documento de donación al enfatizar el lugar por sus muertos ilustres: el dicho señor Condestable avía buen zelo conmo fidelísymo católico cristiano e leal cavallero non solamente del mundo terrenal mas ahún çeleste e divinal a la dicha iglesia santa e su entinción era de onrrar por la dicha su capilla e enterramiento la dicha eglesia ${ }^{106}$.

El documento de donación alude a la petición piadosa del Condestable -...considerando la magnificencia e santidad de la dicha iglesia de Santa María desta dicha çibdat les avía suplicado ... por un logar en dicha iglesia onde él podiese hedificar e nuevamente fazer una capilla para su enterramiento- y al espacio otorgado, las capillas de Santo Eugenio, Santo Tomás Canturiense y Santiago con la llamada casa de los Moldes para sacristía ${ }^{107}$. La donación era espléndida al permitirle derruir tres capillas de la girola - dos grandes y una pequeña - y levantar un amplio recinto fúnebre reproducido en un interesante plano de 1579 conservado en el archivo de la Nobleza de Toledo [figura $\mathrm{n}^{\circ}$ 5]. La inscripción del mismo incide en las dimensiones de la capilla, la calidad de los materiales - ... su riquísima piedra labrada...y la abundante decoración heráldica -... está llena de armas de los Luna...-. Concluye el texto, y subrayamos su pespectiva del siglo XVI al calificar una obra tardogótica, en definirla como la más suntuosa capilla de España ${ }^{108}$.

${ }^{103}$ Calderón Ortega, Álvaro de Luna. Colección Diplomática, n ${ }^{\mathrm{o}} 32$, pp. 97-100. La provisión del maestrazgo fue más teórica que real al coexistir con el gobierno del maestre Enrique similares términos (n ${ }^{\circ} 105$, pp. 329-333). El refrendo de este cargo por el único órgano legitimado, el Capítulo de la Orden, se produjo en Avila los días 31 de agosto y 2 de septiembre (n 107, pp. 335-339).

${ }^{104}$ Calderón Ortega, Álvaro de Luna. Colección Diplomática, no 35, pp. 105-110.

${ }^{105} \mathrm{AHN}$, Osuna, carp. 179, no ${ }^{\circ}$ 14. Pub: Á. GONZÁlEZ PALENCIA, La capilla de Álvaro de Luna en la catedral de Toledo, "Archivo Español de Arte y Arqueología", II (1929), 109-125 y CAlderón OrTega, Alvaro de Luna. Colección Diplomática, n⿳ 33, pp. 101-103.

${ }^{106}$ AHN, Osuna, carp $179, \mathrm{n}^{\circ}$ 14. Pub: CALdERón OrTEGA, Álvaro de Luna. Colección Diplomática, n⿳0 33, pp. 101-103.

${ }^{107} \mathrm{El}$ texto incluye la toma de posesión de este ámbito -contorneo perimetral con un azadón-, el ofrecimiento de canteras y pertrechos según el uso y la cuantificación precisa del tamaño de la capilla resultante: "... sesenta pies en luengo e ocho pies de pared de nueve pies de respaldas onde fueren necesarias, e sesenta pies en lo hueco».

${ }^{108}$ AHN, Nobleza, Osuna, Mapas Planos Dibujos (MPD) 1, D 19. 
La capilla fue iniciada en fechas inmediatas a la donación por el maestro Alvar Martínez y concluida por Hanequín de Bruselas ${ }^{109}$. Sobresalen en ella, como se subraya en el comentado dibujo, los motivos heráldicos de tamaño monumental de sus paredes y las claves de su bóveda estrellada ${ }^{110}$ [figura $n^{\circ} 6$ ].

En otras ocasiones hemos insistido en el valor político-propagandístico dado al tema decorativo de la heráldica e hipotetizado sobre su desarrollo cronológico al hablar del panteón regio de San Juan de los Reyes ${ }^{111}$. La capilla toledana aporta una cronología más temprana y una novedad no improvisada en la seriación de los emblemas, su tamaño y su ubicación. A modo de armorial pétreo, las paredes macizas laterales exhiben el escudo de Álvaro de Luna - cortado de gules y azur con creciente ranversado de azur- rodeado por seis veneras de gules sobre esmalte azur romboidal en una composición casi equiparable al relieve monumental de Santiago matamoros que luce sobre el retablo de la capilla. La misma alternancia heráldica luce en la bóveda. La clave central exhibe un ostentoso escudo del linaje de los Luna, igual que los ángeles tenantes dispuestos en sentido circular en cada una de las ocho nervaduras, mientras que los combados rematan en claves adornadas con veneras. Similar exhibición heráldica aparece en la llamada capilla del palacio de Escalona y, en una versión renovada, se repetirá en la capilla burgalesa de los Condestables. Su confrontación con la capilla tardogótica de los Castrillo en el conventual de Calatrava la Nueva, donde recordemos figura el escudo real en la clave central, plantea en sus justos términos la ambiciosa personalidad del privado, a la vez que contrarresta la crítica más firme realizada por sus detractores: su condición plebeya por línea materna. Fernán Pérez de Guzmán lo expresa malévolamente en su comentario sobre el Condestable: preçiauase mucho de linaje, non se acordando de la homill e baxa parte de su madre $e^{112}$. Queremos incidir en la temprana cronología de esta reiterativa decoración heráldica, como también en la personalidad del maestre Hanequín que, a continuación, trabajó en la capilla funeraria de Pedro Girón cuyas nervaduras también se aditaron con armas nobiliarias.

\footnotetext{
${ }^{109}$ Alvar Martínez figura como testigo en el documento de donación de 1430. Entre esta fecha y 1435 llegó a Toledo el maestro Hanequín y su equipo. Su impronta, presente como hemos visto en la capilla de Pedro Girón, marcará la arquitectura toledana del fin de la centuria. Sobre estos arquitectos vid. J.M ${ }^{\mathrm{a}}$ AZCÁRATE, Arte gótico en España, Madrid, 1990, pp. 115-116 y J. YARZA, La nobleza ante el rey, Madrid, 2003, pp. 127-128.

${ }^{110}$ Las trompas angulares desempeñan un importante papel en el cambio tipológico advertido de la planta al alzado.

${ }^{111}$ A. RuIZ MATEOS, O. PÉREZ MONZÓN y J. ESPINO NuÑO, Manifestaciones artísticas, "Orígenes de la Monarquía hispánica: propaganda y legitimación (ca. 1400-1520)", J.M. NIETO SORIA (dir), Madrid, 1999 , pp. 345 y 367-368 y O. PÉREZ MONZÓN, Quando rey perdemos, nunqua bien nos fallamos. La muerte del rey en la Castilla del siglo XİI, "Archivo Español de Arte", en prensa.

${ }^{112} \mathrm{El}$ literato continúa criticando la prepotencia del privado: «Ouo asaz coraçón e osadía para açebtar e usar de la grande potençia que alcançó, ca o porque duró en ella grant tiempo e se le auía convertido como en natura, o porque su andanzá e presunçión fue grande, mas uso de poderío de rey que de caballero» (F. PERÉZ DE GUZMÁN, Generaciones y Semblanzas, México, 1947 p. 85).
} 
La capilla se aprestó con unos primitivos monumentos tumulares que, según diferentes testimonios literarios, fueron desmontados por el infante don Enrique, adalid de los opositores al privado ${ }^{113}$. Nos referimos a unos versos del propio condestable escritos con motivo de la prisión del infante tras su derrota en la guerra de Nápoles ${ }^{114} \mathrm{y}$, especialmente, al Laberinto de la Fortuna o Las Trescientas de Mena ${ }^{115}$. La particularidad de los mismos, por todos conocida, radicaba en su hechura de cobre o latón dorado y, sobre todo, en el carácter móvil de sus bultos ${ }^{116}$ : ...de muy rica e subtil obra - señala Pedro de Alcocer en 1554- hechos por tal arte que los podían hazer levantar y poner de rodillas cada vez que querían ${ }^{117}$. Estos autómatas fueron destruidos por los principales opositores al noble y su política. Tal hecho parecía presagiar el destino final del maestre, aunque de momento resaltamos la acción: la animadversión al maestre se evidencia en el daño infringido a su imagen igual que, andando el tiempo, en la Farsa de Avila se depone simbólicamente a Enrique IV a través de una estatua suya. La idea enfatiza el

${ }^{113}$ Un puntual estudio de estas fuentes en E. BENITO RUANO, Toledo en el siglo XV, Madrid, 1961 , pp. 36-37. El mismo autor sitúa el desmonte de las figuras en 1441, cuando el hijo de Juan II entró en Toledo.

${ }^{114}$ «Si flota vos combatió, / en verdad, Señor Infante,/ mi bulto non vos prendió,/ quando fueste mareante, / para que hiciésedes nada/ a una semblante figura/ que estaba en mi sepultura/ para mi fin ordenada». Así aparece recogido en la edición de 1499 que Hernán Núñez realizó del texto de Mena donde tambien se indica que el cobre fue llevado al palacio del Condestable de Escalona en carretas. Cit. MENA, Laberinto de la Fortuna, edición NIGRIS, Notas Complementarias, p. 299, copla 265 a-d.

${ }^{115}$ «Ca un Condestable armado, que sobre un grant vulto de oro vimos asentado, con manos sañosas vimos derribado, e todo desfecho fue tornado cobre». Mena, Laberinto de la Fortuna, $\mathrm{p}$. 172 , copla 265. Hernán Núñez incorpora una jugosa glosa al respecto: «Dize aquí el poeta que assí como los leones, costreñidos de grande hambre, tornan a comer contra su costumbre las reliquias y sobrajas del manjar que avían dexado, quando no pueden çaçar carne fresca que coman, assí por semejante las constellaciones y planetas, quando hallan resistencia en las personas en que avían de imprimir sus operaciones imprimenlas en sus semejantes, como en este bulto del condestable. Hermosa comparación e digna de la gracia e sal de Juan de Mena". Cit. MENA, Laberinto de la Fortuna, edición NIGRIS, Notas Complementarias, p. 299, copla 266, p. 299.

${ }^{116} \mathrm{La}$ Europa del siglo XV resucitó la moda de estos artilugios meçánicos, usuales en la tradición bizantina e islámica, a través de los carillones que poblaban la ciudạd. Én la península Ibérica estos usos no desaparecieron; recordemos la "movilidad" de algunas imágenes marianas de las Cantigas o la problemática pieza de las Huelgas llamada Santiago, el del espaldarazo; en cualquier caso, los "bultos" del maestre debieron causar el asombro entre sus contemporáneos y suscitaron la imaginación en las generaciones venideras. En 1787, Antonio Ponz rememoraba estas singulares efigies. «Esta capilla de Santiago la mandó edificar o adornar don Alvaro de Luna estando todavía en su grande elevación; y dicen que aún viviendo se mandó hacer para cuando falleciese un sepulcro de bronce dorado, y en él, su estatua de la misma materia; pero que el infante don Enrique, hijo de Fernando, rey de Aragón, que aborrecía en gran manera al condestable, se lo deshizo todo cuando tomó por armas a Toledo contra el rẹ don Juan» (A. PoNZ, Viaje de España, Madrid, I, 1988, pp. 133-134). Ya a mediados de la siguiente centuria, José María Quadrado glosó su destrucción en los años centrales del siglo XV: «Alguno de estos vaivenes precursores de la gran ruina, ora fuese la irrupción en Toledo del gran infante de Aragón don Enrique hacia 1441, ora el tumulto popular de 1449, derribó el armado coloso "sentado sobre un gran bulto de oro encima del mausoleo que en vida se había erigido el condestable y dispersó y refundió sus fragmentos en cien formas distintas».

${ }^{117}$ P. DE AlCOCER, Historia de la Imperial Cibdad de Toledo, Toledo, 1554, fol. LXXIX. 
concepto, ya codificado en las Partidas de Alfonso $\mathrm{X}^{118}$, de la consideración de las imágenes como sustituto de las personas representadas ${ }^{119}$.

Hasta 1489 no se realizaron los actuales sepulcros [figuras $\mathrm{n}^{\text {os }} 7$ y 8]. Para entender la tardanza en su ejecución, hemos de remontarnos a los sucesos acaecidos en 1453.

El 2 de junio Álvaro de Luna fue ajusticiado en la plaza pública de Valladolid. Su cabeza expuesta durante siete días en la picota y su cuerpo inhumado en el templo de San Nicolás, cementerio de los condenados a muerte y posteriormente trasladado al convento de San Francisco. Es decir, murió en la más absoluta de las deshonras. Las gestiones de la familia Luna, de sus familiares más directos, por otorgar un digno sepulcro al condestable fueron infructuosas durante el reinado de Juan II y, específicamente, de Enrique IV. La situación cambio tras el matrimonio de su hija con un miembro de la familia Mendoza, los grandes aliados de los Reyes Católicos, y de forma específica con el nombramiento en 1482 de Pedro González de Mendoza como arzobispo de Toledo. La viuda y la hija del Condestable reiniciaron las gestiones sobre el traslado del cuerpo y. una vez conseguido el permiso, decidieron revestir de magnificencia el espacio de inhumación familiar.

En 1484, dotaban la capilla con 30.000 maravedíes de renta anual para atender un servicio litúrgico habitual: 3 misas rezadas y una cantada cada semana, más un responso sobre la sepultura. Asimismo, donaban un importante número de alhajas - casullas, cálices, cruz de plata,...-; específicamente un frontal rico de verde rico bordado de oro con las armas de Luna y un paño de brocado... para que se ponga sobre la sepultura del dicho señor maestre mi señor ${ }^{120}$. El documento no precisa el ornato de esta última urdimbre pero, por similitud con otros conservados como el de la capilla de los Condestables destinado igualmente a cubrir el monumento tumular, es factible presuponer un adorno heráldico. Estas piezas, que lucían conjuntamente en las ceremonias fúnebres in memoriam, convertían la capilla en el solemne escenario de exhibición de la familia promotora: los Luna. Resulta obligado plantear los paralelismos con otros escenarios regios como San Juan de los Reyes para cuyo altar mayor Juan Guas ideó un frontal

\footnotetext{
118 «...mandaron que no tan solamente honrrassen al rey los pueblos en quael manera quier que lo fallasen, mas aún a las ymágines que fuesen fechas en assemejança o en figura dél. Por que también la ymagen del Rey, como su sello, en que está su figura, e la señal que trae otro sí en sus armas, e su moneda, e su carta, en que se nombra su nome, que todas estas cosas, deven ser mucho honrradas, porque son en su remembranza do él non está» (ALFONSO X, Segunda Partida, Título XIII, Ley XVIII).

${ }^{119}$ Estas consideraciones, de forma más precisa, en O. PÉREZ MONZÓN, Quando rey perdemos, nunqua bien nos fallamos.

${ }^{120}$ La dádiva incluye varias casullas -una de terciopelo negro- frontales diversos, «una cruz de plata con su pie dorada toda que pesa çinco marcos con una mançana de seys esmaltes, un cálice todo dorado con su patena que pesa çinco marcos el pie labrado con la estoria de la Pasión e un misal toledano en pergamino para ornar e serviçio de la dicha capilla». El documento también precisa el impedimento de prestar estos ornamentos o sacarlos de la capilla (AHN, Nobleza, Osuna, leg. 1734-4²).
} 
adornado con el yugo y las flechas ${ }^{121}$. Además, aunque los cenotafios reales no llegaron a realizarse, en su lugar se colocó un monumento fúnebre adornado con tapicería real convertido en la referencia simbólica de los oficios de difuntos celebrados en el monasterio franciscano ${ }^{122}$. Una similar costumbre existió en la catedral de Granada con la disposición de dos tumbas entre la dich a capilla mayor de la dicha iglesia y el coro de ella e aya ocho çirios que ardan en todo el tiempo de las onrras ${ }^{123}$.

Fallecida Juana de Pimentel, su hija María, duquesa del Infantado por su matrimonio con Iñigo López de Mendoza, culminó el ornato de la capilla con el encargo de unos nuevos monumentos tumulares a Sebastián de Toledo (7 de enero de 1489) ${ }^{124}$. De sus cláusulas contractuales, relativas a la tasación -90.000 maravedís - , el material y la iconografía, queremos insistir de forma especial en la obligación paralela del escultor de realizarlos en Guadalajara, ciudad de residencia de María de Luna, y de entregarlos acabados y asentados en la capilla de Toledo. Si el trabajo en la ciudad alcarreña, facilitaba a María de Luna controlar la ejecución de los mismos, también permite pensar en el establecimiento de un taller que, dada la proximidad geográfica pudo realizar el sepulcro del doncel de Sigüenza.

De formato rectangular, mantienen la moda tradicional en la representación del finado como yacente. La mayor originalidad de los sepulcros alabastrinos son los cuatro caballeros santiaguistas cuya pose genuflexa y vestimenta aparecen minuciosamente descritas en el contrato: la una rodilla ahinojada e la otra enhiesta, jaquetas e ropetas alimnas, espadas çeñidas, espuelas... ${ }^{125}$. Sobresale su tamaño casi natural aunque, según los documentos mencionados, la novedad iconográfica debió corresponder al cenotafio del maestre Girón ${ }^{126}$. Su gesto perenniza el rito del homenaje al señor, recordemos que son freires reverenciando a la máxima dignidad de la Orden, emulando la ceremonia de la toma de posesión de los maestres de Órdenes Militares que incluía una ceremonia de homenaje/vasallaje -el besamanos- y otra de reconocimiento de la nueva dignidad con la imposición de sus atributos respectivos. Álvaro de Luna, tras su juramento como maestre en 1445, recibió la espada, el sello, el pendón y el birrete ${ }^{127}$. Precisamente, este es el sombrero que luce en la tapa sepulcral.

${ }^{121}$ Vid. T. PÉrez Higuera, Proyecto para la iglesia de San Juan de los Reyes de Toledo, "Isabel la Católica. La magnificencia de un reinado", Valladolid, 2004, pp. 279-280.

${ }^{122}$ Cit. DOMÍngunez CASAS, San Juan de los Reyes: espacio funerario y aposento regio, "Boletín del Seminario de Arte y Arqueología", LVI (1990), 364-383.

${ }^{123}$ AGS, Privilegios Reales, 25-44, fol. 5.

${ }^{124}$ AHN, Nobleza, Osuna, leg. 1733, no 66. Pub. J.M. DE AzCÁRATE, El Maestro Sebastián de Toledo y el doncel de Sigüenza. "Wad-al-Hayara", I (197,4), nota n ${ }^{\circ}$ 30, pp. 30-32 y J. CARRETEPARRONDO, Sebastián de Toledo y el sepulcro de don Alvaro de Luna, "Revista de Ideas Estéticas", no 131 (1974), pp. 37-43.

${ }^{125} \mathrm{AHN}$, Nobleza, Osuna, leg. 1733, $\mathrm{n}^{\circ}$ 66. Pub. CARrete y PARrondo, Sebastián de Toledo y el sepulcro de don Alvaro de Luna, p. 40.

${ }^{126} \mathrm{Si}$ bien es cierto que en éste, las figuras angulares eran ángeles y su tamaño era menor. 334-339.

${ }^{127}$ Calderón Ortega, Álvaro de Luna (1419-1453). Colección diplomática, $\mathrm{n}^{\mathrm{o}}$ 107, pp. 
La pose genuflexa también evoca el solemne ritual de la deposición del cuerpo en su lugar de inhumación como conclusión de la procesión fúnebre, comitiva que nunca tuvo al maestre como protagonista ${ }^{128}$. La cláusula contractual parece sugerirlo al precisar el gesto de los freires: que tengan una mano baxo la solera de las molduras del sepulcro y la obra arriba, como que la tienen en peso ${ }^{129}$.

El túmulo inmortaliza un rito habitual en las exequias. Es lo que hemos denominado un "momento detenido" de la realidad que también apreciamos en otras obras coetáneas. Citamos, por ejemplo, la lectura ensimismada de Martín Vázquez de Arce, el símil de oratorio donde se ubica el infante don Alfonso en la cartuja de Miraflores o el sepulcro del obispo Alonso de Burgos con el cincelado en tamaño natural de una plática del obispo ante los diferentes miembros de la familia real. Las obras citadas, la última desgraciadamente destruida, coinciden en su cronología tardogótica. Quizá tienen como resabio la "composición de lugar" que plantea Ludovico de Sajonia en el acercamiento del hecho religioso al fiel o sencillamente forman parte de una corriente tendente a inmortalizar en piedra secuencias privativas del finado. En cualquier caso, se trata de escenografías de gran efecto visual.

Las paredes del sepulcro ocupan sus encasamentos con ángeles tenantes del escudo de los Luna y de la Orden de Santiago ${ }^{130}$ - y la representación de virtudes. El texto no precisa cuáles, sólo la convivencia de las teologales y las cardinales, a la vez que otorga un valor específico a su tamaño - e que sean asentadas e que hinchen toda la pieça quanto mayor podiere $\operatorname{ser}^{131}-$, hecho que ligamos al valor conceptual otorgado a estas imágenes ${ }^{132}$.

Se ha señalado en repetidas ocasiones la inspiración de esta iconografía en la literatura especular donde un buen gobernante se equipara a un hombre virtuoso. Pensamos que la representación de las virtudes puede tener un significado más polisémico definiendo asimismo a un buen militar. En $\mathrm{La}$ Coronación del Marqués de Santillana de Juan de Mena, Iñigo López de Mendoza recibe de las virtudes cardinales la corona de laurel como símbolo

${ }^{128}$ Vid. P. LENAGHAN, Conmemorating a real bastard: the chapel of Alvaro de Luna, "Memory and the Medieval Tomb", edited by E. VALDEZ DEL ALAMO with C. STAMATIS PENDERGAST, Cambridge, 2000, pp.'140-141.

${ }^{129} \mathrm{AHN}$, Nobleza, Osuna, leg. 1733, no 66. Pub. CARrete y PARrondo, Sebastián de Toledo y el sepulcro de don Alvaro de Luna, p. 40.

${ }^{130}$ «... que haya cuatro escudos de las armas de dicho maestre con sus orlas alrededor de las armas, en que haya ocho veneras, e entiéndase quatro escudos alrededor de dicho sepulcro uno a la cabecera y otro a los pies y otros dos en medio de los costados, metydos dentro de los encasamientos de las chambranas, con dos ángeles en cada escudo que los tengan con sus alas» (AHN, Nobleza, Osuna, leg. 1733, n ${ }^{\circ}$ 66. Pub. CARRETE Y PARRONDO, Sebastián de Toledo y el sepulcro de don Alvaro de Luna, p. 40).

${ }^{131} \mathrm{AHN}$, Nobleza, Osuna, leg. 1733, no 66. Pub. CARrete y PARRondo, Sebastián de Toledo y el sepulcro de don Alvaro de Luna, p. 41.

${ }^{132}$ La pérdida de algunos atributos dificulta su identificación. E. FERNÁNDEZ considera que corresponden a las cuatro virtudes cardinales (Don Alvaro de Luna, condestable de Castilla, maestre de Santiago, p. 158). 
de valentía y de sus éxitos militares ${ }^{133}$. La finalidad más evidente de la Coronación es la exaltación de Santillana por sus méritos, y específicamente por la aventura militar de la reconquista de Huelma $(1438)^{134}$. Bajo este prisma, entendemos que la representación de las virtudes en el cenotafio de Álvaro de Luna proclaman su condición de buen gobernante y buen militar como hechos relevantes de su biografía ${ }^{135}$. Participa de la misma intención, la inscripción ordenada por la duquesa del Infantado:

\section{AQUI YACE EL ILUSTRE SEÑOR DON ALVARO DE LUNA \\ MAESTRE DE SANTIAGO Y CONDESTABLE QUE FUE DE CASTILLA \\ EL CUAL DESPUES DE HABER TENIDO LA GOBERNACION DE \\ ESTOS REINOS POR MUCHOS AÑOS FENESCIÓ SUS DIAS EN EL MES DE JULIO AÑO DEL SEÑOR DE 1453.}

En 1488, María de Luna encargó a Sancho de Zamora, Juan de Segovia y Pedro de Gumiel el retablo de la capilla con las tablas del maestre y su mujer en posición orante ${ }^{136}$. Lo más particular del retablo, en este contexto de priorización de la figura del maestre, es el probable empleo en su iconografía del Libro de las claras e virtuosas mugeres escrito por el propio condestable según la interesante tesis sugerida por Etelvina Fernández ${ }^{137}$. En cualquier caso, conviene señalar que no es excepcional la traslación de un texto poético a materia artística como constata el retablo de los Ángeles (1455)

\footnotetext{
133 «La fuente circuncingían/ los actores palancianos, / cuando hevos do venían/ nueve donas que traían/ sendos cetros en las manos/ en los cuales reportaban/ un palio, do se loaban/ bien las manos del platero, / y debaxo un caballero/ a quien todas acataban./... Respondió con gran falago:/"A quien tú vees que fago/ tan gran despensa de honor,/ es de Mendoça señor,/ đẹ la Vega y de Buitrago". /... Dixo: "Magueră complida/ su alma consigo está,/ él vive doblada vida, y tiene silla escogida/ así allá como acá;/ por lo cual te concluimos/ que al que nos sigue seguimos/ no podrá la muerte tanto/ que le despoje del manto/ que nosotras le vestimos". / Sus fablas fueron cessando, / ca los sabios al estruendo/ se iban ya levantando/ so una voz exclamando/ y en muy altas proponiendo,/ y diziendo en un tropel:/ "Bien puede venir aquel/ que quiso con nos morada, / trayendo tan bien ganada/ la corona de laurel". / En gran cátedra de ver/ le dieron asentamiento.../ De entre las ramas más bellas/ de aquel selvático seno,/ salieron quatro doncellas/ más claras que las estrellas/ con el nocturno sereno;/ las cuales, cantando enante/ el romance de Atalante/ circundaron su persona,/ y le dieron la corona/ sobre todas illustrante. /... La Prudencia y Temperança/ la Justicia y Fortaleza/ dan por su cierta balanca/ perdurable bienandanza/ que vale más que riqueza;/ por ende, sed envidiosos/ d'este bien los cautelosos, / las vestigias imitando/ del que vive perdonando/ vuestro vicios odiosos» (J. DE MENA La Coronacion del Marqués de Santillana, "Antología de su obra poética", edición de J.M ${ }^{a}$ ÀZÁCETA, Bilbao, 1986, pp. 138-144).

${ }^{134}$ MeNA, Laberinto de la Fortuna, ed. NIGRIs, Prólogo, p. XLVII.

${ }^{135}$ Lo meditado de esta iconografía, se constata al compararlo con el sepulcro de la condesa de Montalbán, su pendant, donde las estatuas angulares son frailes franciscanos y los encasamentos laterales se destinaron a sus armas nobiliarias y parejas de apóstoles que fasen el credo.

${ }^{136} \mathrm{AHN}$, Nobleza, Osuna, leg. 1734, $\mathrm{n}^{\circ} 4^{3}$ Pub. C. GonZÁLEZ PALEnCIA, La capilla de don Álvaro de Luna en la catedral de Toledo "Archivo Español del Arte", 13 (1929), pp. 109-112. Las cláusulas contractuales precisan su pose, su vestimenta y, en el caso de la pintura, el acompañamiento por santos tutelares. San Francisco para el Condestable y San Antonio de Padua para la condesa. No es accidental la elección franciscana si recordamos que el confesor de Juana Pimentel fue Juan de Medina, fraile franciscano de la observancia. El matrimonio dirige sus oraciones a una Piedad, tema muy característico del tardogótico y propio de ámbitos fúnebres.

${ }^{137}$ La citada investigadora otorga una explicación a las restantes figuras hagiográficas (Don Álvaro de Luna, condestable de Castilla, maestre de Santiago, pp. 159-160). El documento no especifica la titularidad de estos santos y exclusivamente alude a una relación que tenía que entregar la duquesa.
} 
de Jorge Inglés encargado por Iñigo López de Mendoza donde los ángeles e inclusive el mismo noble portan cartelas con versos o gozos de la Virgen escritos por el propio marqués de Santillana. María de Luna, hija del maestre, tuvo que conocer la obra pictórica patrimonio de los Mendoza y, con el empleo de esta fuente de inspiración, en el retablo de la capilla toledana se incidiría en la vertiente de Álvaro de Luna como literato.

En suma, la valoración conjunta de estas piezas proclaman a la dignidad santiaguista como buen gobernante, hombre de armas y hombre de letras haciendo olvidar su muerte sin honor.

\section{De Palacios y CASAS MAESTRALES}

La ruina y el menoscabo han afectado de forma notable el patrimonio civil de las Órdenes de Calatrava y Santiago. Diferentes trabajos de Aurora Ruiz Mateos, basados fundamentalmente en libros de Visitas, han señalado el mantenimiento en las Casas de la Encomienda de la tipología en torno a un patio central ${ }^{138}$. Los edificios más notables tuvieron oratorios privados, jardines con cenadores y ámbitos de deleitación. La çasa buena de Argamasilla de Alba de la Orden de Calatrava tenía un oratorio y un huerto bien tratado para recreación y la de Corrral de Caracuel, de la misma institución, un vergel poblado con naranjos, árboles, rosas y un estanque de peces ${ }^{139}$. La frecuencia de estos elementos se subraya en la residencia del Tribunal de la Inquisición de Llerena, perteneciente a la Orden de Santiago. Los documentos hablan de un vergel y huerta que tiene unos olivos y perales y otros árboles... no tiene naranjos porque con el yelo se han quemado, tiene un pozo de agua como anoria... y, a la parte de arriba, ... está un cenadero con sus almenas y parral alto que lo cubre... Junto al dicho zenadero está una alberquilla ${ }^{140}$.

Los maestres también intervinieron en edificios simbólicos de la Orden como la Casa de los Maestres de Almagro, recientemente convertida en Museo Nacional del Teatro y necesitada de un estudio monográfico ${ }^{141}$ [figura $\mathrm{n}^{\circ}$ 9]. De tal forma, Luís González de Guzmán construyó la capilla de San Benito - hoy desaparecida- en sustitución de un primitivo oratorio donde se celebraron algunos Capítulos de la Orden. La estancia religiosa estaba cubierta por una techumbre de madera elogiada por los visitadores: buena madera de pino pintada, lavor muy rica e firme e fermosa, toda fecha de

\footnotetext{
${ }^{138}$ Arquitectura civil de la Orden de Santiago en Extremadura: la Casa de la Encomienda. Su proyección en Hispanoamérica, Madrid, 1985.

${ }^{139} \mathrm{AHN}$, OOMM, leg. 6080, $\mathrm{n}^{\circ}$ 6, fol. 3 y leg. 6078, $\mathrm{n}^{\circ} 20$, fol. $201 \mathrm{v}$.

${ }^{140} \mathrm{AHN}$, OOMM, libro $1012 \mathrm{c}$, fols. $111 \mathrm{v}$. Pub. A. RuIz MATEOS, Residencias del tribunal de la Inquisición de Llerena en palacios santiaguistas, "Actas del Simposio "El Arte y las Ordenes Militares", Cáceres, 1985, p. 261.

${ }^{141}$ Como referencia, destacamos el trabajo de J. ESPINO NuÑo, El palacio de los Maestres de la Orden de Calatrava en Almagro en el siglo X $V$ : nuevos datos documentales acerca de su construcción, "Anales de Historia del Arte. Homenaje al Profesor Dr. D. José María de Azcárate y Ristorí", 4'(1993-1994), pp. 91-100.
} 
nuevo e muy honrosa para el lugar donde está142. Subrayamos el epíteto de honrosa como exponente de un cierto nivel artístico. Su sucesor en el cargo, el maestre Pedro Girón, realizó labores de mantenimiento en la construcción maestral manteniéndola reparada e solada e enlozida e pintada e guarnecida y operó en dos nuevas crujías del piso alto del patio que aderezó con sus armerías y cruces de Calatrava ${ }^{143}$ [figura $n^{0} 10$ ] . La convivencia de emblemas, ya empleada por el maestre, Guzmán, refleja el proceso de aristocratización vivido en el seno de las Órdenes Militares.

La situación descrita culmina en los maestres que tuvieron su residencia palatina privativa. Nuevamente, vuelve a destacar Álvaro de Luna, propietario del castillo de Escalona donde, igual que en la capilla funeraria y con el mismo sentido legitimador, se emplearon sistemáticamente como ornato sus armerías.

La Crónica de Álvaro de Luna permite visualizar con mayor nitidez este espacio de magnificencia a través de las descripciones de las ceremonias y fiestas - justas, torneos, banquetes, ...- que allí se celebraban ${ }^{144}$. Las salas estaban engalanadas con ricas tapicerías:

Después que entraron dentro de la cassa, fallárosla muy guarnida de paños françeses, e de otros paños de seda e de oro, e muy ordenada de todas las cosas que conbenían; e todas las cámaras e salas estaban dando de sí muy suabes olores ${ }^{145}$.

Tampoco faltaban aparadores llenos de vajillas de oro y piedras preciosas. Qué la ciudad de Barcelona honrase al Maestre con una copa de oro, que tenía en la sobrecopa muchas piedras de gran valía, e de esmerada perfiçión, constata el valor dado a estos objetos ${ }^{146}$.

Participaba de los gustos cortesanos del momento, el adorno de los jardines del palacio con plantas aromáticas, cenadores y vistosas jaulas para animales. La Crónica, además, al evocar el ornato de la entrada con cabezas de osos, puercos, animales salvajes y la piel de un león obsequiada por un rey moro ${ }^{147}$ constata la afición del coleccionismo bajomedieval por lo particular, lo exótico e incluso lo extravagante ${ }^{148}$. Un similar espacio de placer y deleitación tuvo el cardenal Pedro González de Mendoza en su residencia de Guadalajara con gallinas africanas, grullas o ánades púrpura, según la

\footnotetext{
${ }^{142} \mathrm{AHN}$, OO MM, libro 1412c, fol. 19.

${ }^{143}$ AHN, OO MM, leg. 6109 , fol. $1 \mathrm{v}$.

${ }^{144}$ Trata con detenimiento estos aspectos Fernández GonZÁLEZ, Don Álvaro de Luna, pp. 145-148.

${ }^{145}$ Crónica de Álvaro de Luna, cap. LXXIV, p. 219.

${ }^{146} \mathrm{El}$ privado ofreció esta pieza a Juan II en una de las fiestas a las que acudió (Crónica de Álvaro de Luna, cap. LXXIV, p. 220).

${ }^{147}$ Crónica de Álvaro de Luna, cap. LXXIV, p. 219.

${ }^{148}$ Vid. M. Bolaños, Historia de los Museos en España. Memoria, cultura, sociedad, Gijón, 1997, pp. $15-57$
} 
descripción de Jerónimo Münzer que cataloga el edificio como de los más bellos de toda España ${ }^{149}$.

Los invitados a estos festejos no iban a la zaga en magnificencia destacando sus suntuosas vestimentas y los espectaculares joyeles que exhibían. En unas fiestas realizadas en honor del rey, fueron sacadas muy ricas ropas, ca el Condestable avía dado a todos ropas de seda, e alli salieron borladuras e invenciones de mиy nuevas maneras, e muy ricas cintas e collares e cadenas, e joyeles de grandes prescios, con finas piedras e perlas, e muy ricas guarniciones de caballos e facaneas; en tal manera que toda aquella corte relumbraba e resplandecía ${ }^{150}$. Deslumbrante fue, asimismo, el regreso a la Corte del privado tras su primer destierro ${ }^{151}$ y espectaculares las joyas que don Álvaro cedió al rey por sus esponsales. La descripción de las mismas nos sitúa en el gusto, nuevamente, hacia lo exótico y extravagante ${ }^{152}$.

El deseo de sorprender se manifiesta en el empleo de artificios de gran teatralidad como el engalanamiento nocturno de una sala con tantas hachas que paresçía que fuese de muy claro día que para su mejor disposición estaban colgadas altas del çielo de la sala por unos filos de aranbre assí sotiles, que las calaban a la larga, que parecía que en el ayre se tenían ${ }^{153}$.

\section{DE LIBROS Y OTRAS DÁDIVAS}

Maestres y comendadores enriquecieron los edificios de sus órdenes respectivas con la entrega de suntuosos objetos litúrgicos utilizados tanto para el uso particular de cada capilla fúnebre como para el culto del templo. Todos ellos incorporan como ornato la armería del donante, en clara sintonía con los usos mantenidos por la nobleza secular ${ }^{154}$. Apreciamos en estas dadivas las dos coordenadas que el encargo de obras artísticas siguió en el tardogótico: la obra de autoría o valor material y la producción estandarizada ${ }^{155}$.

\footnotetext{
${ }^{149}$ Viaje por España y Portugal (1494-1495), Madrid, 1991, pp. 283-284.

${ }^{150}$ Crónica de don Álvaro de Luna, cap. XIV, p. 53.

${ }^{151}$ «.... allí fueron traydos plateros, argenteros, e bordadores, e sastres de la corte del Rey e aun de fuera del reyno, los quales muchos días fueron ocupados en fazer guarniçiones de oro e de plata, e cintas, e cadenas, e ropas, e otras bordaduras muy ricas, quales antes non avían parecido en la corte» (Crónica de don Álvaro de Luna, cap. XVII, p. 67).

${ }^{152}$ «... un joyel que se llama de la Serena que es fecho en figura de una doncella e tiene un rrubí en medio grande e debaxo del rubí una esmeralda grande con dos perlas grandes a manera de peras e otro joyel grande rredondo en que ay siete perlas grandes commo avellanas mondadas, un cafir grande e otro joyel que se llama la prensa en que está un diamante punta mayor que es un avellana con su cáscara» [J.M. CALDERÓN ORTEGA, Alvaro de Luna (1419-1453). Colección Diplomática, Madrid, 1999, pp. 364-366, no 116].

${ }^{153}$ Crónica de don Álvaro de Luna, cap. LXXIV, p. 221.

${ }^{154}$ En Uclés, este patrimonio llegó a ser espléndido necesitando tres piezas de almacenaje: la sacristía, el tesoro y el relicario (AHN, OOMM, libro 1086c, fol. 153).

${ }^{155}$ Sobre el interesante capítulo de la producción "al por mayor" resultan de obligada consulta los artículos contenidos en diferentes catálogos: El esplendor de Flandes. Arte de Bruselas, Amberes y Malinas en los siglos XV-XVI, Barcelona, 1999; El fruto de la fe. El legado artístico de Flandes en la isla de la Palma, Madrid, 2004; Lumen canariense. El Cristo de la Laguna y su tiempo, Tenerife, 2004.
} 
De tal forma, el maestre santiaguista Rodrigo Manrique donó al convento de Uclés los órganos en sus caxas de madera pintadas situados a ambos lados del coro y una cruz de plata sobredorada con unos escudos de las armas de los Manriques y Acuña que presumiblemente se empleó en sus oficios fúnebres in memoriam ${ }^{156}$. El prior Fernando Santoyo entregó una espléndida custodia de plata para el mismo edificio ${ }^{157}$ y el maestre Álvaro de Luna, enterrado en Toledo, una escultura de plata de Santiago peregrino ${ }^{158}$. La documentación no precisa si ésta última se integró en un retablo o se mantuvo como escultura exenta. En la misma línea, en el convento de Calatrava la Nueva se inventarían varias cruces - de cristal, madera, aljobar y plata-, relicarios, cálices y arquetas con útiles privativos de las capillas funerarias ${ }^{159}$. La de Luís de Guzmán, por citar un ejemplo, tenía varias vestimentas, un portapaz, una cruz de plata de gajos con su pie e unas imágenes, un relicario y un incensario de plata con sus cadenas e adereço con su naveta e cuchara de plata señalada de sus armas ${ }^{160}$.

Otras dádivas tuvieron un menor valor artístico. El maestre Lorenzo Suárez de Figueroa cedió sendas imágenes alabastrinas del santo jacobeo a los Hospitales Generales que la Orden tuvo en Cuenca y Toledo ${ }^{161}$. La apostilla del escribano, de las del maestre Lorenzo Suárez de Figueroa, sugiere un mayor número de piezas entregadas y la similitud de las mismas, lo que nos lleva a relacionarlas con la producción estandarizada de alabastros ingleses ${ }^{162}$.

Formaba parte de los intereses del momento la afición por los libros. Álvaro de Luna fue protagonista de algunos textos y autor conocido de otros como el citado de las Virtuosas e claras mugeres. Un ejemplar manuscrito de este texto formaba parte de la colección de Isabel I; la heráldica de los Luna presente en su encuadernación lo señala como presente del privado ${ }^{163}$. No fue el único ofrendado a los monarcas. El 8 de marzo de 1504, Violante de Albión, camarera de la reina, recibió un Libro de Horas Ricas de Álvaro de

\footnotetext{
${ }^{156} \mathrm{AHN}$, OOMM, libro 1086c, fol. 9. La cruz tenía en el anverso la representación de la Deesis y en el reverso un Agnus Deei acompañado de los cuatro evangelistas (el documento dice cuatro apóstoles, pero debe ser un error del escribano).

${ }^{157}$ La alhaja tenía en su peana escudos de su donante y un letrero que señalaba su identidad (AHN, OOMM, libro 1086c, fols. 11).

${ }^{158}$ «Una ymagen de plata de bulto dorada de nuestro patrón y señor Santiago en figura de peregrino . dizen que dio esta ymagen de señor Santiago el maestre don Alvaro de Luna» (AHN, OOMM, libro $1086 \mathrm{c}$, fol. 9).

${ }^{159}$ AHN, OOMM, leg. 6109, $\mathrm{n}^{\circ}$ 29, fol. 177.

${ }^{160}$ AHN, OOMM, leg. 6109, $\mathrm{n}^{\circ} 29$, fol. $177 \mathrm{v}$.

${ }^{161} \mathrm{AHN}$, OOMM, libro $1076 \mathrm{c}$, fol. 205 y libro $1086 \mathrm{c}$, fol. $89 \mathrm{v}$.

${ }^{162}$ Las imágenes se "personalizaban" con la inclusión de un escudo del maestre en la peana. Vid. O. PÉREZ MONZÓN, El Hospital de Santiago de Toledo en el siglo XVI, "Actas del IX Congreso Español de Historia del Arte", I, León, 1994, p. 364, nota ${ }^{\circ} 64$.

163 "... de pergamino, de mano, que es de las Virtuosas e Claras mugeres que hizo el maestre don Âlvaro de Luna, con una camisa de carmesí pelo, forrado en tafetán azul; y tiene de cada parte un quadro de plata dorado y esmaltado grande, en que está un escudo leonado, las armas de Luna e quatro veneras de plata dorada a los cantones, e la una venera de la una parte está suelta, e tiene las charnelas e manos de las çerraduras de la misma plata, con unas veneras e cruzes en dos texillos blancos e corales». Pub. F.J. SÁNCHEZ CANTÓN, Libros, tapices y cuadros que coleccionó Isabel la Católica, Madrid, 1950, p. 50.
} 
Zúñiga, prior de la Orden de San Juan de Jerusalén como atestiguaban los escudos de la encuadernación ${ }^{164}$. Sin embargo, ningún encargo tuvo la espectacularidad de la llamada Biblia de la Casa de Alba promovida por el maestre calatravo Luís González de Guzmán.

\subsection{La Biblia de Alba y Luis González de Guzmán}

En 1422, el maestre de Calatrava Luís González de Guzmán encargó al rabino Moisés Arragel de Guadalajara la traducción de la Biblia al romance. El resultado de ese trabajo, ya culminado el 2 de junio de $1430^{165}$, es la llamada Biblia de la Casa de Alba (Palacio de Liria, ms. 399) ${ }^{166}$.

La petición maestral se encuadra dentro de las iniciativas promovidas por personalidades nobles $-\mathrm{y}$ también regias- de conseguir traducciones comprensibles del texto sagrado, debido a su deficiente entendimiento del latín. Guzmán, receloso de estas transmisiones, encargó a Arragel la traducción directa del hebreo; aunque la versión definitiva fue supervisada por personalidades cristianas de la confianza del maestre ${ }^{167}$. La dignidad calatrava, además, quería glosas con explicaciones de los fragmentos más oscuros e ilustraciones que clarificaran su contenido. Una Biblia en rromançe, glosada e historiada fue exactamente la petición del maestre. Todo ello nos sitúa en una personalidad no excesivamente preparada en la exégesis del libro sagrado, circunstancia no infrecuente entre la nobleza de su tiempo. Puede sorprender algo más por tratarse de un maestre, cabeza visible de una institución religiosa, pero no debemos olvidar que se trata también del máximo

${ }^{164} \mathrm{El}$ documento incorpora la relación de las miniaturas que ornamentan este libro de devoción y la descripción precisa de su encuadernación: «El qual dicho libro tiene unas cubiertas de azeituní carmesí traídas, guarneçidas en çebtí carmesí con un cayrel alderredor de oro hilado, e quatro borlas con quatro botones del dicho oro; con un rregistro angosto cincelado de oro de martyllo, donde están puestos los ministros con que se rrigen las dichas Oras. Y tyenen más dos escuditos pequeños del dicho oro, esmaltados de blanco y negro con una vanda en cada uno de Çúñiga, donde se penden unos fechos con unas charnelas, que son tan largos como tres dedos e tan anchos cada uno como un dedo, del dicho oro de martyllo, esmaltados de rrosycler e verde e blanco, saltados los esmaltes en algunas partes, los quales se van a prender en dos escuditos del dicho oro de martyllo, esmaltados de blanco e negro con la divha vanda de Çúñiga... Las quales dichas Oras enbió en servicio a su Alteza don Alvaro de Cúñiga, prior de San Joan» [ÄGS, Contaduría Mayor de Cuentas, 1 época, leg. 178, pliego XC. Pub. E. RUIZ, Orígenes de la monarquía hispánica. propaganda y legitimacion (ca. 1400-1520), pp. 416-417, doc. n $\mathrm{n}^{\mathrm{O}}$ ].

${ }^{165}$ Según PAZ Y MELIA, los trabajos de revisión y corrección del texto pudieron alargarse hasta 1433. El rabino, morador de la villa calatrava de Maqueda, afirmó que había empleado once años en su trabajọ que valoraba en 1.000 doblas (La Biblla puesta en romance por rabi Mosé Arraguel de Guadalfajara, "Homenaje a Menéndez Pelayo", II, Madrid, 1989, pp. 6, 12 y 18).

${ }^{166} \mathrm{Ha}$ dedicado diversos trabajos al manuscrito S. FELLOUS destacando, especialmente, $L a$ Biblia de Alba. L'iconographie ambigüe, "Creencias y Culturas. Cristianos, judíos y musulmanes en la España medieval"”. C. CARRETE PARRONDO y A. MEYUGAS GIMIO (eds.), Salamanca, 1998. 41-96 y Tolède 1422-1433. Histoire de la Bible de Moïse.Arragel. Quand un rrabin interprète la Bible pour les chrétiens, París, 2001. Interesantes, asimismo, resultan los trabajos de C.O. NORDSTRÖM, The Duke of Alba's Castilian Bible. A Study of the Rabbinical Features of the Miniatures, Uppsala, 1967. J. YARZA LUACES, La imagen del rey y la imagen del noble en el siglo $X V$, pp. 281-284; A. DoMínGUEZ RODRÍGUEZ, Dos Biblias iluminadas en Toledo en torno a 1420: La Biblia de Alba y la "Biblia romanceada escurialense” (Escorial, Ms. I.J.3), "Flanders in a Europe Perspectiva", Leuven, 1995, pp. 473-485.

${ }^{167}$ Vid. YARZA LUACES, La nobleza ante el rey, pp. 279-280. 
representante del brazo secular de una Orden sometida a un creciente proceso de aristocratización.

El manuscrito tiene dos partes netamente diferenciadas: el texto sagrado propiamente dicho que, en este caso, es sólo el Antiguo Testamento y un prólogo de 25 folios donde, a modo de los tradicionales colofones, se realiza una micro-historia sobre los prolegómenos y avatares de la elaboración del libro ${ }^{168}$. Los datos comentados tienen básicamente esta fuente de información.

Todo el texto se ilustra con miniaturas de diferente formato que los especialistas han vinculado a talleres toledanos ${ }^{169}$ y han juzgado de forma dispar pasando del elogio (Caamaño Martínez) ${ }^{170}$ al comedimiento en su valoración estética (Domínguez) ${ }^{171}$. Ciertamente no nos hallamos ante una obra excepcional, pero sí de notable calidad. En las escenografías, el/los miniaturista/s muestra/n un interés en la representación del espacio -no resuelto de forma acertada en la mayoría de los casos- cercano a las propuestas trecentistas italianas ${ }^{172}$. Paralelamente, los ademanes de los personajes, la riqueza - a veces con tintes de extravagancia- de los atuendos, el valor concedido a lo secundario y la estética de lo curvilíneo y amable delatan un conocimiento de la moda internacional, lo que por otra parte coincide con las fechas de ejecución del manuscrito ${ }^{173}$.

En este trabajo sobre la imagen nobiliar, vamos a centrar nuestra atención en las dos miniaturas del prólogo que tienen a Guzmán como protagonista. Ambas publicitan una imagen representativa - no fisonómicadel maestre llena de resabios nobiliarios y, más específicamente, regios.

La primera imagen alude al encargo de la Biblia: el envío de la misiva al rabino Arragel (fol. 1). Guzmán descansa en un trono-asiento concebido como cátedra episcopal o sitial regio; hablamos de un emplazamiento preferente cuya altura se equipara a la del edificio limítrofe. El maestre, además, sujeta en su mano derecha un halcón, en referencia al distinguido arte

\footnotetext{
${ }^{168}$ Vid. S. FELLous, Dialogue et Prologue dans la Biblia d'Albe”, "Les Prologues et Préfaces de la Bible, XVème-XVIIème siècles", D. RouSSEL y J.D. BuboIS (coord.), París, 1997, pp. 359-376.

${ }^{169}$ Según PAZ Y MELIA, los miniaturistas pudieron seguir en su trabajo las instrucciones del franciscano Arias de la Encina con el precedente de la Biblia del Sagrario de la catedral de Toledo (La Biblia puesta en romance por rabí Mosé Arraguel de Guadalfajara, p. 10).

${ }^{170}$ Este autor lo definió como el más rico manuscrito iluminado del siglo XV castellano [J. CAAMAÑ MARTíNEZ, Arquitectura y artes plásticas, "La época del gótico en la cultura española (c.1220-c.1480)", Historia de España Menéndez Pidal, vol. XVI, Madrid, 2000, p. 740].

${ }^{171} \mathrm{La}$ citada especialista considera las miniaturas torpes y alejadas de las composiciones espaciales trecentistas y de la elegancia de la estética internacional; como peculiaridad de las mismas, resalta su influencia hebrea [DOMínGUEZ, Dos Biblias iluminadas en Toledo en torno a 1420, p. 474].

${ }^{172}$ YARZA LUACES vincula estos trabajos a la impronta dejada por Gerardo Starnina en la ciudad primada (La imagen del rey y la imagen del noble en el siglo XV, p. 281). Sobre este foco artístico vid. la monografía de M.A.B. PIQUERO LOPEZ, La pintura toledana anterior a 1450 (el Trecento), 2 vols., Toledo, 1984.

${ }^{173}$ CAAMAÑO ya resaltó la fuerte impronta internacional en este trabajo (Arquitectura y artes figurativas, p. 740 ).
} 
de la cetrería $^{174}$ y viste túnica ribeteada en piel, conforme a la moda generalizada en las clases altas ${ }^{175}$. Atributos, ademanes y vestimentas subrayan la condición nobiliar del maestre [figura $\mathrm{n}^{\mathbf{0}} 11$ ].

En la última miniatura del prólogo (folio 25 v), el maestre Guzmán recibe de Arragel la traducción del texto sagrado. Lo particular de la misma es que la escena de presentación, lejos de centralizar la secuencia, configura el nivel inferior de una composición piramidal en cuyo vértice figura el maestre en perspectiva jerárquica. Por esta acertada inversión de secuencias, la miniatura transforma el tema inicial en una imagen mayestática de la dignidad maestral ${ }^{176}$ [figura $\mathrm{n}^{\mathrm{0}} 12$ ].

Los atributos del Maestre, bajo esta óptica, adquieren una especial relevancia. Guzmán enarbola altivamente la espada ${ }^{17}$, en un gesto con resabios regios ${ }^{178}$; le flanquean dos maceros empleados en otras miniaturas como imágenes metonímicas de los palacios regios ${ }^{179}$ y sobrevuela su cabeza un ángel con el pendón ferpado, símbolo de la dignidad maestral que con el

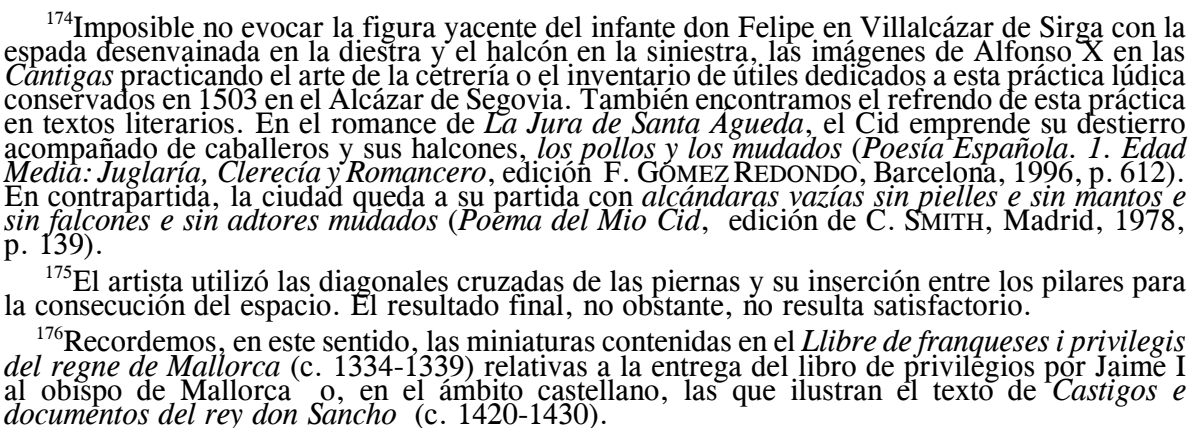

${ }^{177}$ Las Partidas reiteran insistentemente el símil espada-justicia al hablar del quehacer regio, como ejemplifican las frases: "rey taja los males del reino cọn la espada de la justicia» y «el nome del Rey es de Dios e tiene su lugar en tierra para hazer justicia» (ALFONSO X, Segunda Partida, Título IX, Ley XXVII y Título XIII, Ley I). Por el contrario, los actos indecorosos son incompatibles con la posesión de este arma. En la Crónica de Jiménez de Rada, Witimiro fue desarmado de la espada por los godos tras gritar cosas irreverentes ante el altar mariano (Historia de los Hechos de España, int. trad. notas e índices de J. FERNÁNDEZ VALVERDE, Madrid, 1989 Libro 3, Cap. V, pp. 25-26); en la misma línea, se encuadra la penalización impuesta en las Partidas a los malos caballeros de cortarles las espuelas o la espada que tuviesen ceñida (ALFONSO X, Sétima Partida, Título VI, Ley IIII).

Sobre el simbolismo de la espada vid. B.'PALACIOS MARTín, Los símbolos de la soberanía en la Edad Media española. El simbolismo de la espada, "VII Centenario del infante don Fernando de la Cerda", Ciudad Real, 1976, pp. 273-296 y J. FLORI, J., L'ideologie du glaive. Prehistoire de la chevalerie, Ginebra, 1983.

${ }^{178}$ Lo normal es que figure el arma envainada apoyada en el suelo, en posición de descanso, imitando con su arriaz el dibujo de una cruz. En contadas ocasiones, el arma luce desenvainada. Nos referimos al desaparecido simulacro de Fernando III en la catedral de Sevilla, a algunas imágenes regias de la galería de antepasados del Alcázar de Segovia, la pose altanera del infante Felipe en Villalcázar de Sirga o, como nos interesa especialmente destacar, las imágenes de Salomón y del rey Sancho IV en el citado texto de Castigos e documentos. En todos los casos, se alude al monarca luchador e invicto, mensaje que es asumido por el maestre en su cualidad de máxima dignidad de una institución religioso-militar.

${ }^{179}$ Las miniaturas de Castigos e documentos, muy esquemáticas en su concepción espacial, coinciden con las de la Biblia de Alba en la representación metonímica de la corte a través de pajes con mazas. Las comentadas imágenes de Guzmán y Salomón exhiben una pareja de esțos servidores perfectamente afrontados. De momento, no podemos precisar si estas coincidencias obedecen a un mismo taller artístico. 
gesto de su mano le designa como el elegido por la divinidad a modo de una sacralización de su poder ${ }^{180}$. Gestos y atributos priorizan la dignidad maestral representada en Diego Guzmán.

En el registro intermedio de esta miniatura, figura la secuencia múltiple de las siete obras de misericordia. Escritores de la época como Fernán Pérez de Guzmán o Pero López de Ayala escribieron sobre esta secuencia también evocada en los sermones de la época. Sin embargo, la representación seriada de las siete obras de misericordia no es un tema artístico frecuente y, quizá por esa causa, el miniaturista completó cada secuencia con una cartela donde se escribe la acción aludida. Apuntamos una relación entre el carácter didáctico y ejemplar de esta escena con las prácticas empleadas en el ars predicandi, específicamente con los sermones del dominico Vicente Ferrer que acompañaba la claridad de su discurso hablado con actuaciones de penitentes, flagelantes y catequistas que, entre otros actos, hacían obras de misericordia ${ }^{181}$. La miniatura parece inmortalizar estas representaciones que animaban las calles y los templos; además, Ferrer pertenecía a la orden dominica, igual que el encargado de la supervisión del texto. Precisamente, dos figuras clericales interpretadas como el dominico Juan de Zamora - revisor del texto- y el franciscano Arias de Encina - colaborador de Arragel - actúan, a modo de paréntesis, como cierre de esta escena caritativa. No aparece ninguna referencia iconográfica al brazo clerical de la Orden calatrava en una miniatura que ilustra el texto sagrado por antonomasia en un nuevo signo de la preponderancia de los elementos laicos sobre los clericales, materializada en la atmósfera eminentemente cortesana que predomina en toda la composición y que tan alejada resulta de la espiritualidad conventual característica de una orden religiosa.

La escena se representa con un esteriotipo de caballero calatravo, considerado como una personificación de la propia institución religioso-militar realizando estas obras con personajes necesitados o como una alusión al propio maestre ${ }^{182}$. Participamos de esta última interpretación señalada por Yarza que personaliza en la dignidad calatrava la práctica de la caridad convertida en un lugar común de los actos piadosos del siglo XV y que, por extensión, corresponde a una Orden de dimensión religiosa y hospitalaria.

En el registro inferior de la miniatura, una hilera de caballeros calatravos se interrumpe en su centro para enfatizar la entrega por el rabino

\footnotetext{
${ }^{180}$ Los resabios de la iconografía regia resultan nuevamente evidentes. Luís de Guzmán sujeta el Libro Sagrado, mientras que envuelve su túnica de terciopelo con una elegante capa blanca decorada con la cruz de Calatrava. El mismo distintivo llevan los caballeros calatravos de la base. Si éste se acomodó a las disposiciones de la bula de Benedicto XIII de 1397, no así las prescripciones referidas al uso del escapulario cisterciense. En su lugar, los calatravos visten túnicas de tonos variados y vistosos con remates de pieles conforme a la moda aristocrática de la época claro indicio del proceso de, aristocratización que experimentó la institución Vid. RODRÍGUEZ-PICAVEA y PEREZ MONZÓN, Mentalidad, cultura y representación .

${ }^{181}$ Estas prácticas cultuales son señaladas por I. SANZ SANCHO Iglesia y religiosidad " $\mathrm{La}$ época medieval. Iglesia y cultura", J.M. NIETO SORIA e I. SANZ SANCHO, Madrid, 2002, p. 235.

${ }^{182}$ Suscribe esta última opinión YARZA LUACES, La imagen del rey y la imagen del noble en el siglo $X V$, p. 282.
} 
Moisés Arragel de la Biblia traducida a Luis de Guzmán ${ }^{183}$. La imagen reproduce la fórmula iconográfica característica de las escenas de presentación codificadas en la miniatura alfonsí tanto en el asunto -ofrecimiento del mandato ya cumplido - como en la resolución compositiva - pose genuflexa del autor y priorización del mecenas - ${ }^{184}$. La sustitución del rey por el maestre en la Biblia de Alba es un claro indicio de las aspiraciones de este último.

El poder visual de esta imagen adquiere un especial relieve al apreciar los paralelismos planteados en la Biblia de Alba entre la miniatura del maestre Guzmán y la del rey bíblico Salomón (fol. 235 v) desde el diseño organizativo hasta la entronización y perspectiva jerárquica de los dos protagonistas pasando por la representación alegórica del sitial del gobernante israelita tanto en las doce cabezas de leones (miniatura de Salomón) como en los seis peldaños simbólicos (miniatura de Guzmán) ${ }^{185}$. La literatura del momento es prolija en la enumeración de figuras veterotestamentarias que se consideran modelo/precedente del oficio rea ${ }^{186}$. En ocasiones, estas asociaciones tuvieron un correlato artístico como la galería de monarcas bíblicos que Gil de Siloé cinceló en las paredes del cenotafio de Juan II de la Cartuja de Miraflores (Burgos). En la Biblia de Alba, frente a otros referentes bíblicos, se opta por Salomón como paradigma de gobernante justo y sabio.

Acompañan las imágenes del maestre, otras relativas al rabino Arragel. En el folio 1, le encontramos detrás de su atril entre los teólogos cristianos que supervisan la traducción y, en el folio 2, escuchando sumisamente las instrucciones del franciscano Arias. La iconografía retoma las secuencias de las lecciones ex cátedra con un profesor orador ante un púlpito, aquí convertido en un elevado atril, y un público oyente, reducido en la miniatura a la figura del rabino. Una tercera miniatura muestra el homenaje del rabino, proskynesis incluida, al rey Juan II (fol. 2). Identificamos a los personajes por las cartelas que portan, presentando un particular interés la del texto del traductor: su siervo rraby mose.

Si las miniaturas parecen justificar el encargo de la traducción al rabino, con fama de hombre docto, subrayando la supervisión en la elaboración y resultado final de los teólogos cristianos y la fidelidad del judío hacia el monarca castellano; el mayor interés de la Biblia de Alba estriba en las protagonizadas por Luís González de Guzmán como resumen de las dos facetas de su biografía: la naturaleza monárquica de la institución maestral que ejercía y su condición de noble perteneciente a uno de los más antiguos linajes castellanos. El maestre controla el encargo y su contenido, promoviendo un

\footnotetext{
${ }^{183}$ Arragel, a diferencia de los lampiños caballeros calatravos, tiene barba y círculo distintivo de su condición de judío.

${ }^{184} \mathrm{Ha}$ analizado esta iconografía A. Domínguez RodRíGUEZ, La miniatura en la Corte de Alfonso X, Madrid, 1992.

${ }^{185}$ Ambos elementos definían el trono del gobernante israelita (L. RÈAU, Iconografía del arte cristiano. Antiguo Testamento, Tomo 1/Volumen 1, Barcelona, 1996, pp. 342-343).

${ }^{186} \mathrm{El}$ fundamento bíblico se encuadra en el proceso de legitimación y afianzamiento de la monarquía (J. M., NIETO SORIA, Fundamentos ideológicos del poder real en Castilla, siglos XIIIXVI, Madrid, 1988, pp. 60-78).
} 
mensaje favorable a su figura y sus intereses a través de la palabra escrita, las imágenes y la propia obra en su conjunto.

$$
* * *
$$

Como conclusión, y a tenor de lo visto, cabe subrayar como la nobleza calatrava y santiaguista manifestó unas idénticas preocupaciones artísticas a las de la aristocracia laica; lo que refleja una particular visión del mundo y una idea de la fama post mortem bastante alejadas de los ideales de una institución religiosa y militar.

Fecha de recepción del artículo: febrero 2007.

Fecha de aceptación y versión final: julio 2007. 


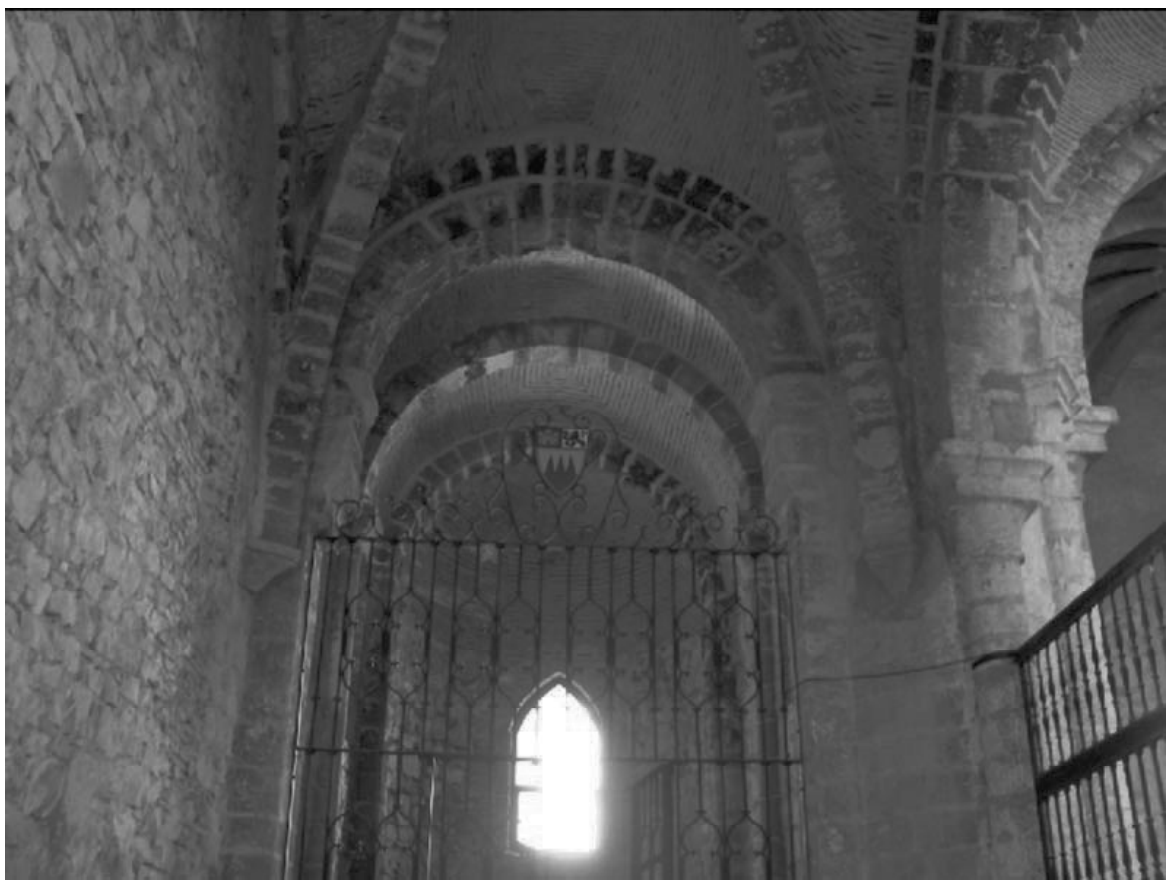

Figura 1. Estado actual de la capilla de Pedro Girón en la iglesia del Conventual de Calatrava la Nueva (Ciudad Real) 


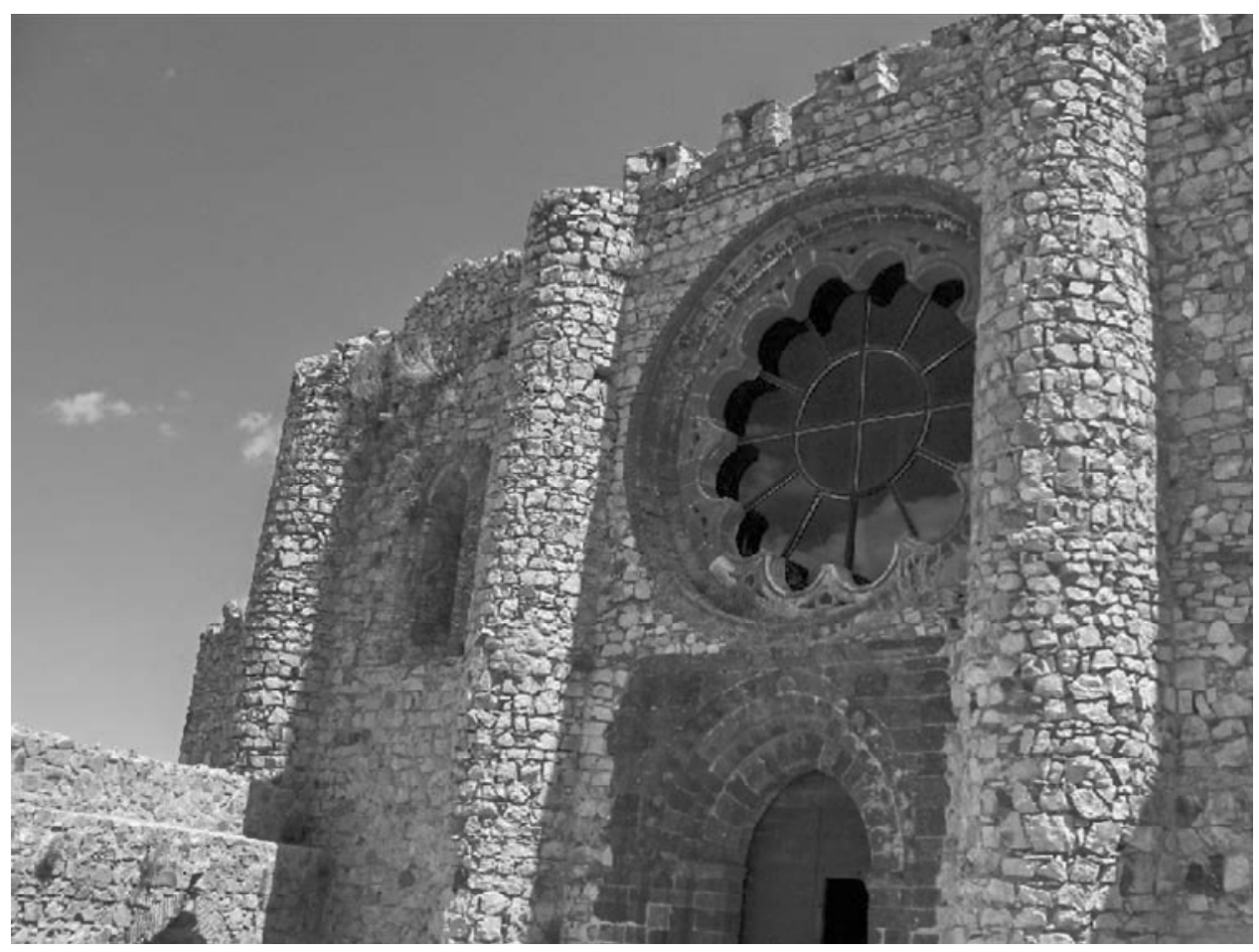

Figura 2. Entrada de la Iglesia del Conventual de Calatrava la Nueva. A la izquierda, los muros de la capilla de Diego García del Castrillo. 


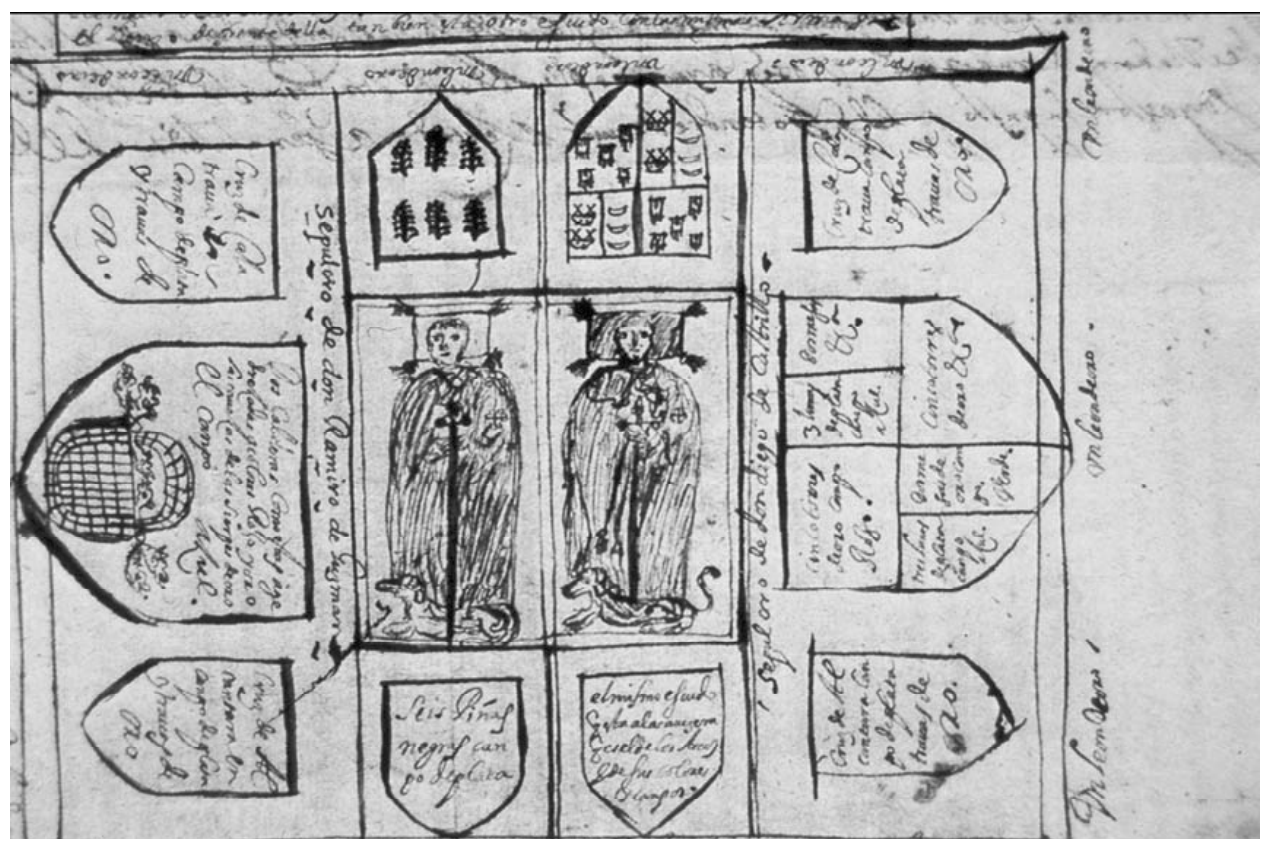

Figura 3. Dibujo de los sepulcros de la capilla de Diego García de Castrillo en la iglesia de Calatrava la Nueva. ca. 1632 (Archivo Histórico Nacional, Nobleza, Bornos 826/4). 


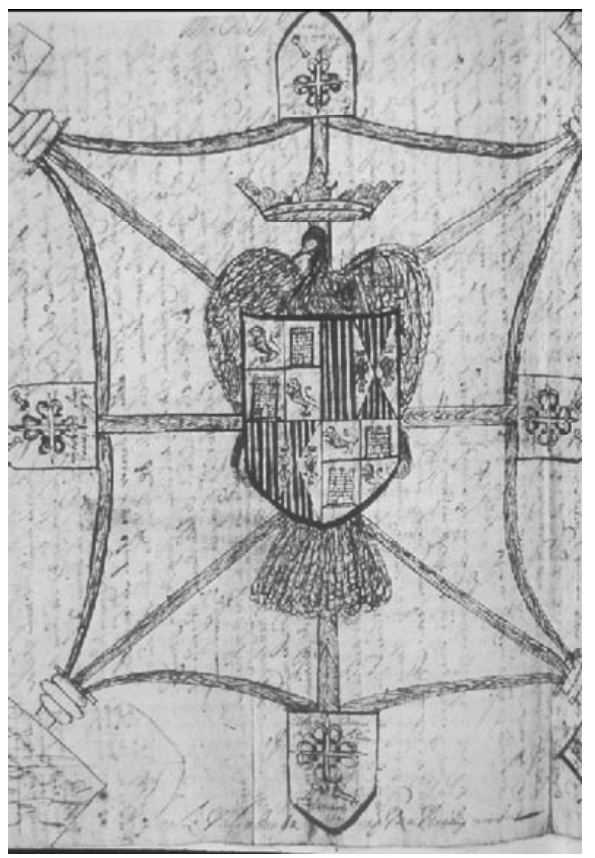

Figura 4. Dibujo de la bóveda de la capilla de Diego García de Castrillo en la iglesia de Calatrava la Nueva (Archivo Histórico Nacional, Nobleza, Bornos 826/4). 


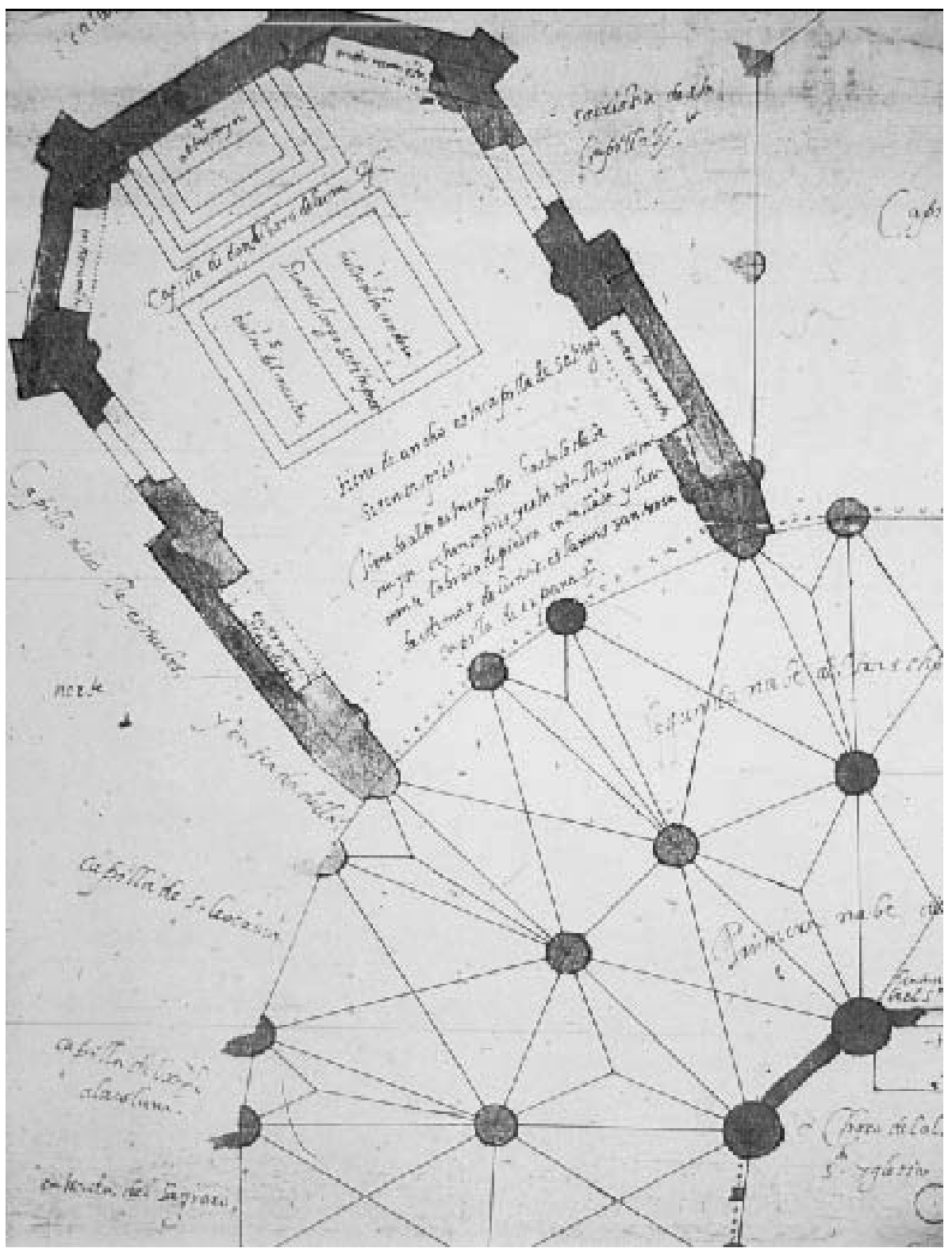

Figura 5. Planta de la capilla de Álvaro de Luna en la catedral de Toledo. ca. 1579 (Archivo Histórico Nacional Nobleza, Osuna, Mapas Planos Dibujos 1, D 19) 


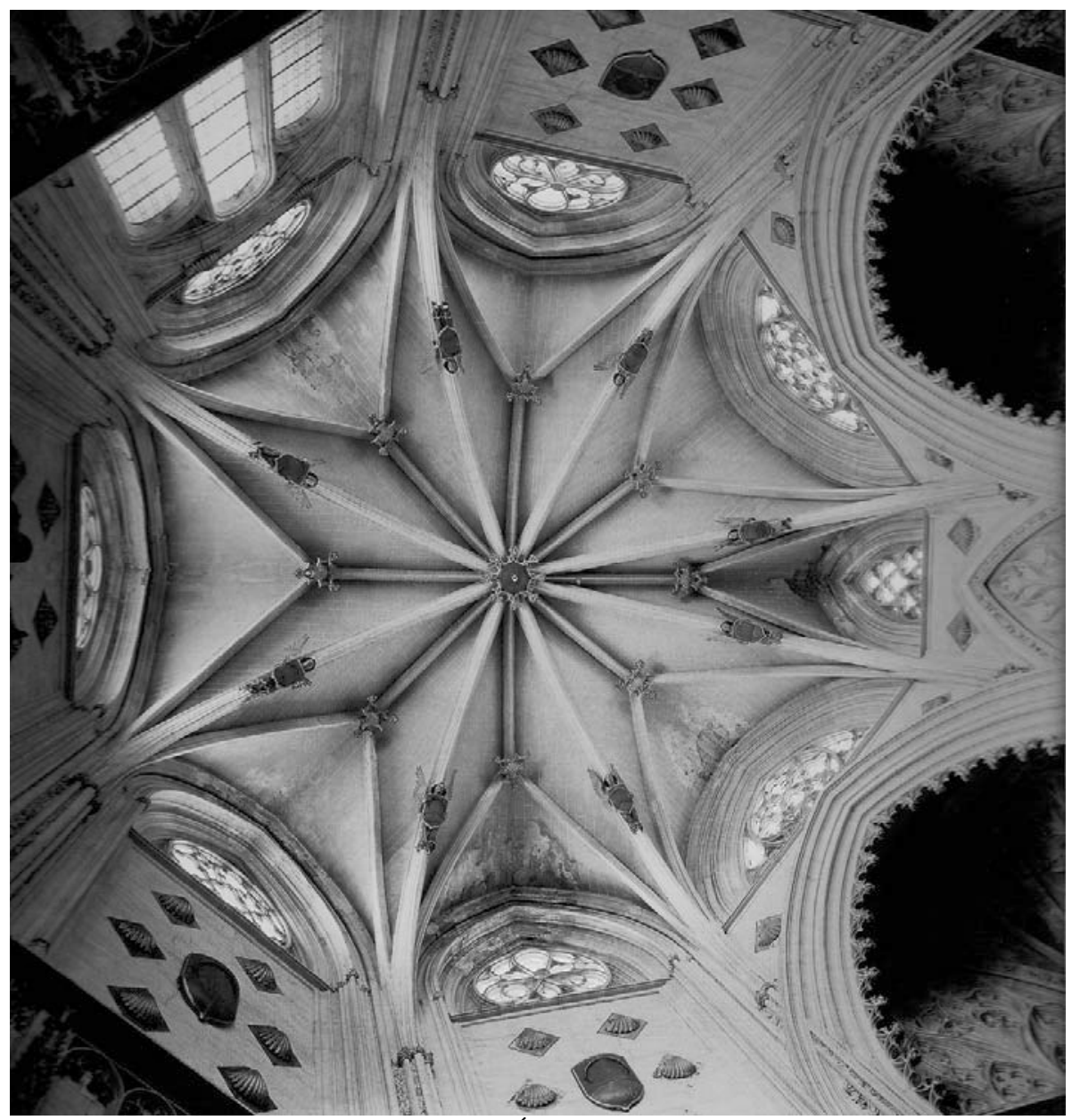

Figura 6. Bóveda de la capilla funeraria de Álvaro de Luna. Siglo XV (catedral de Toledo). 


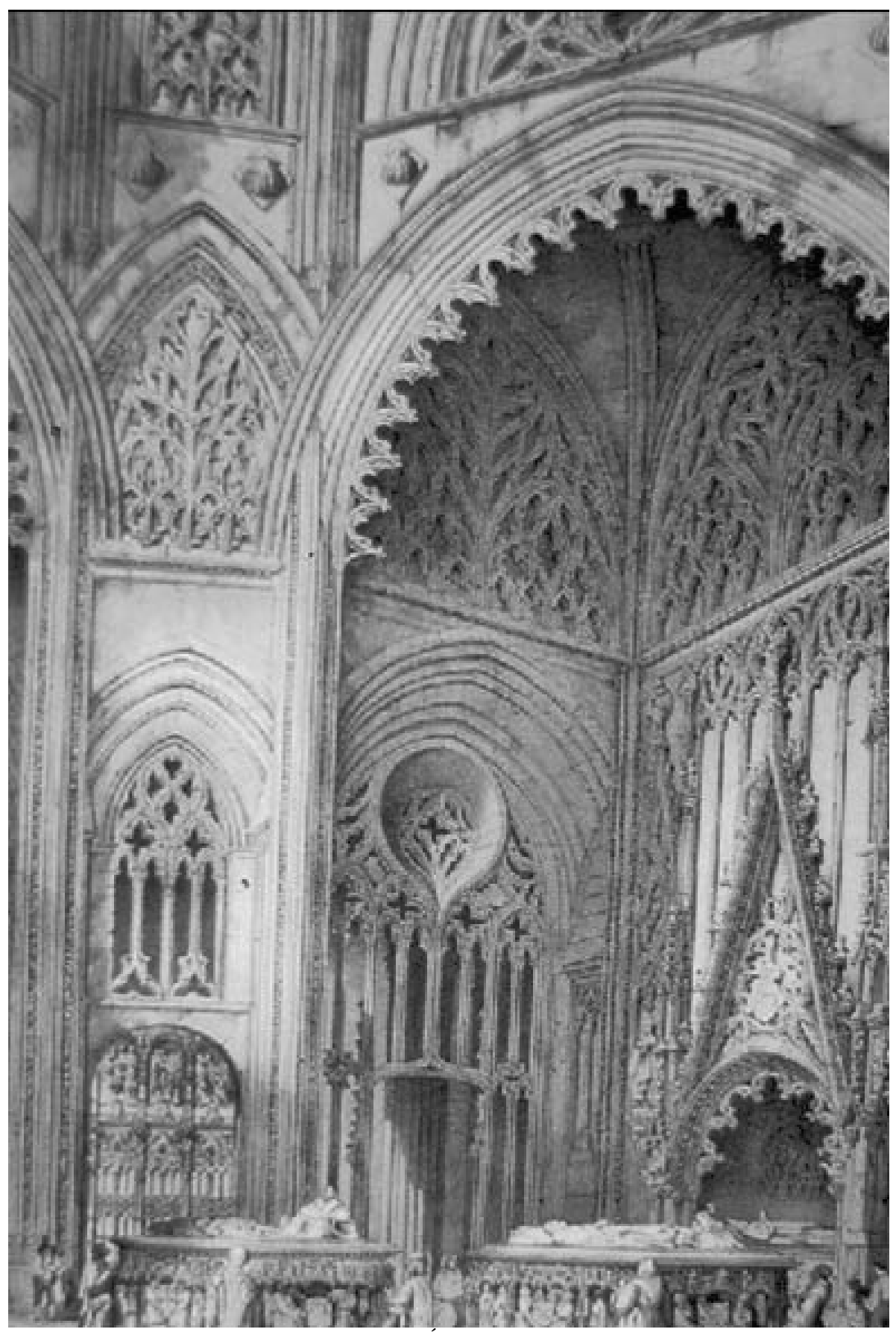

Figura 7. Capilla de Álvaro de Luna, según un grabado de Parcerisa. 


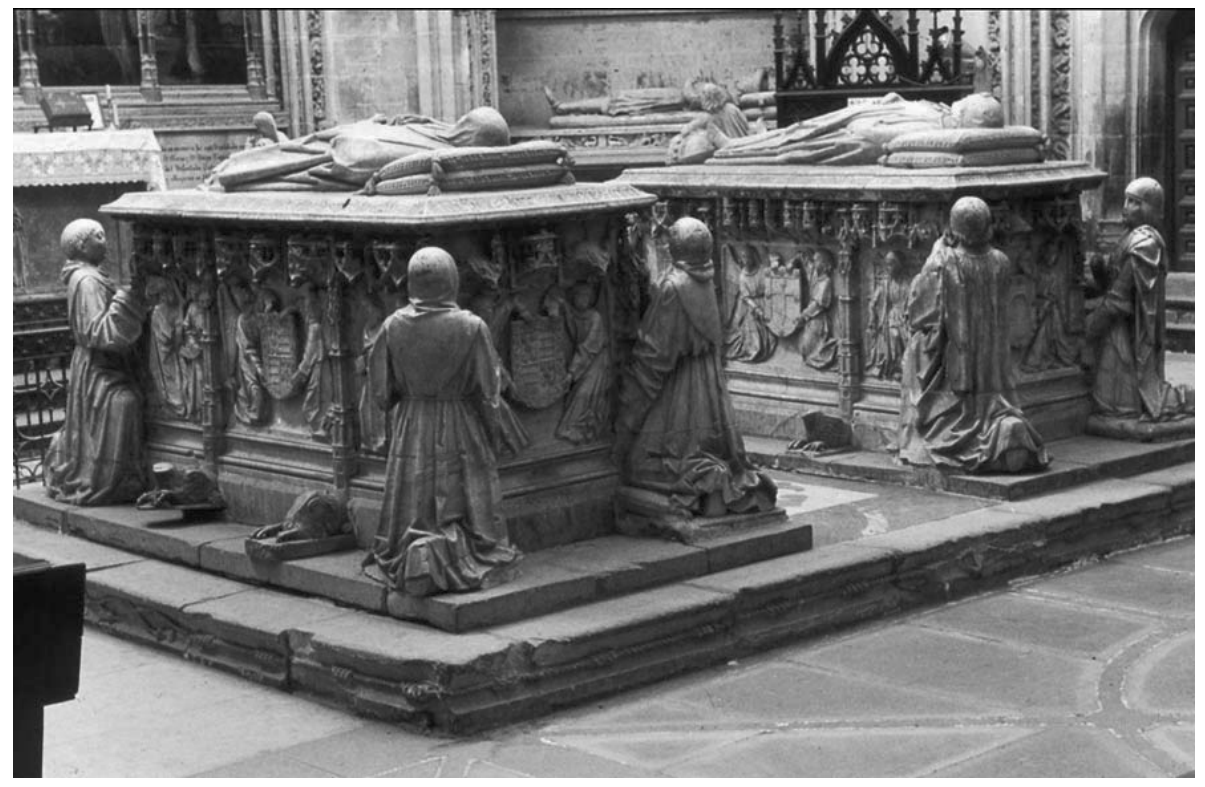

Figura 8. Sepulcros de Álvaro de Luna y Juana de Pimentel (catedral de Toledo) 


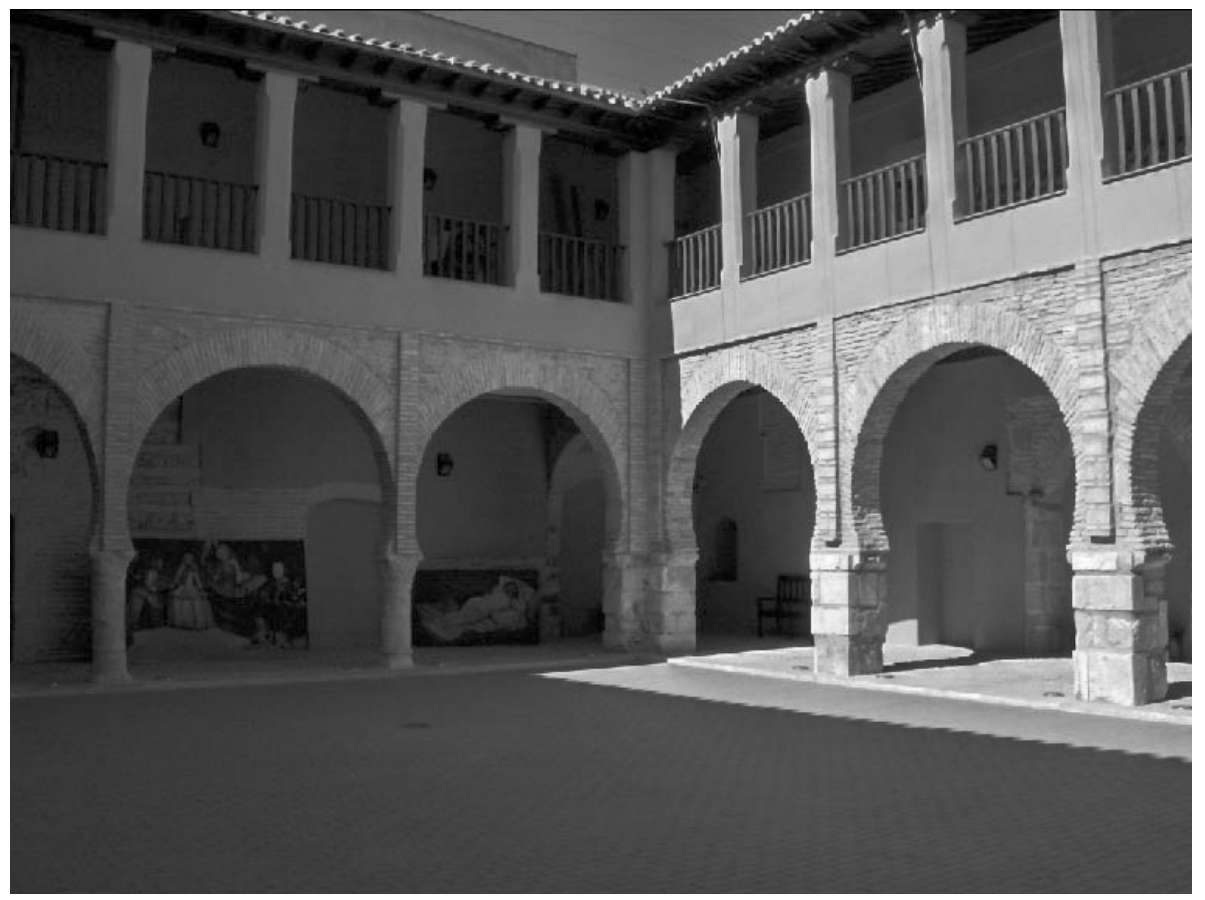

Figura 9. Patio del Palacio de los Maestres de Almagro (Ciudad Real). 


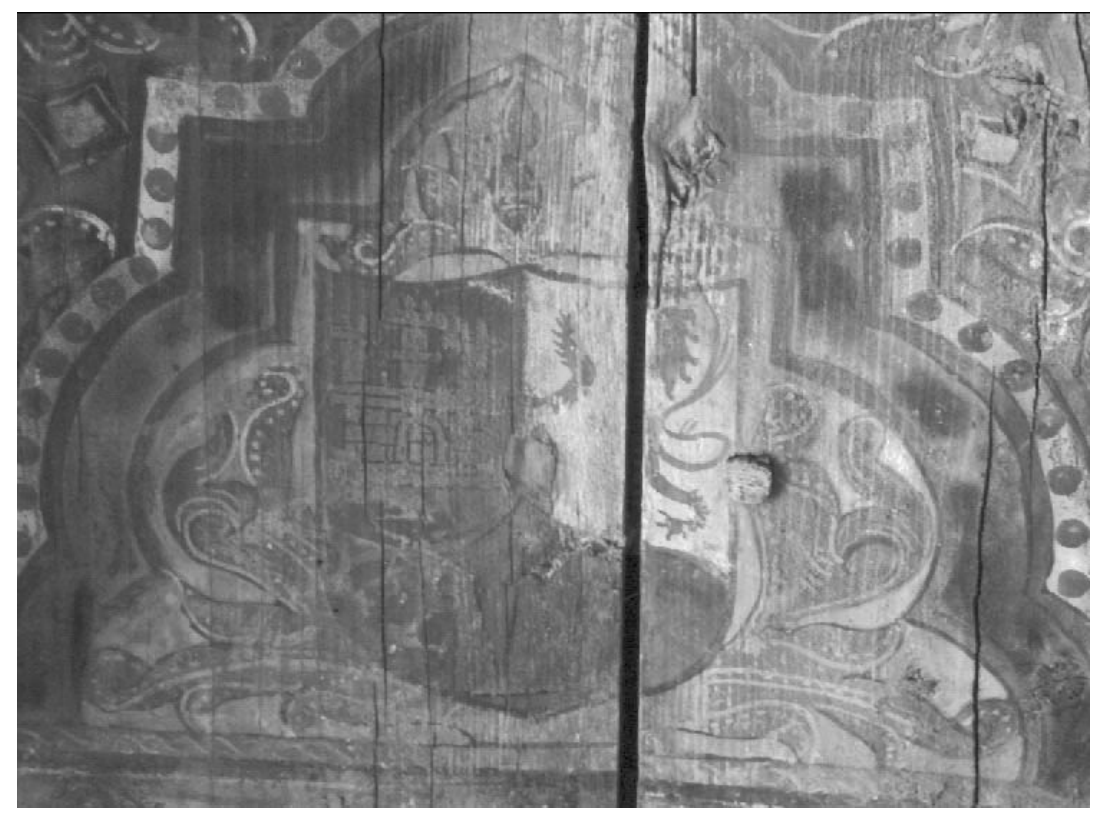

Figura 10. Detalle del patio del Palacio de los Maestres de Almagro con el escudo de Pedro Girón 


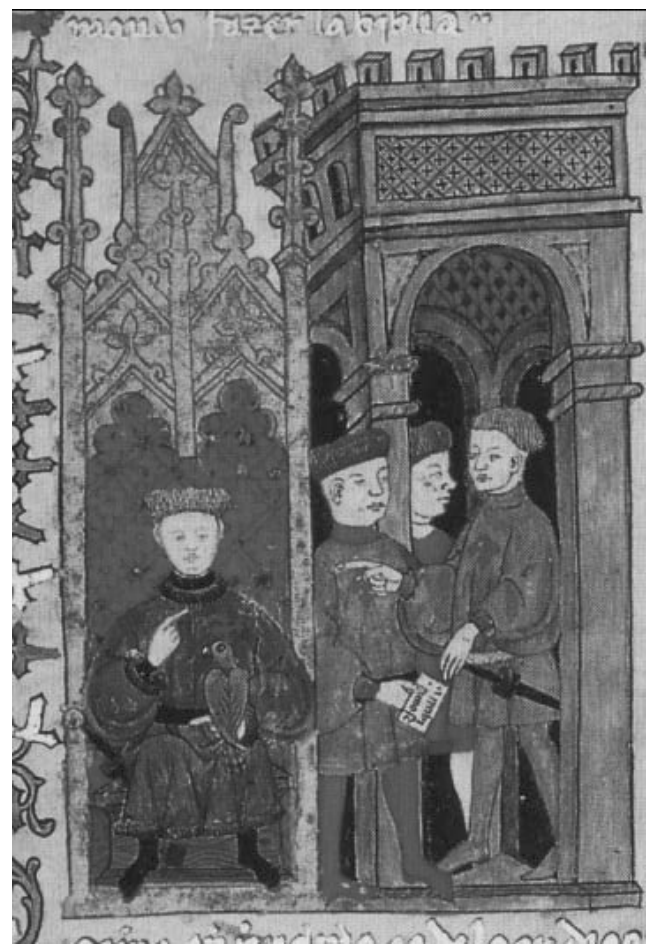

Figura 11. Encargo de la Biblia a Arragel por Luis González de Guzmán. Biblia de Alba. ca. 1430. (Madrid, Palacio de Liria, ms.399, fol. 1) 


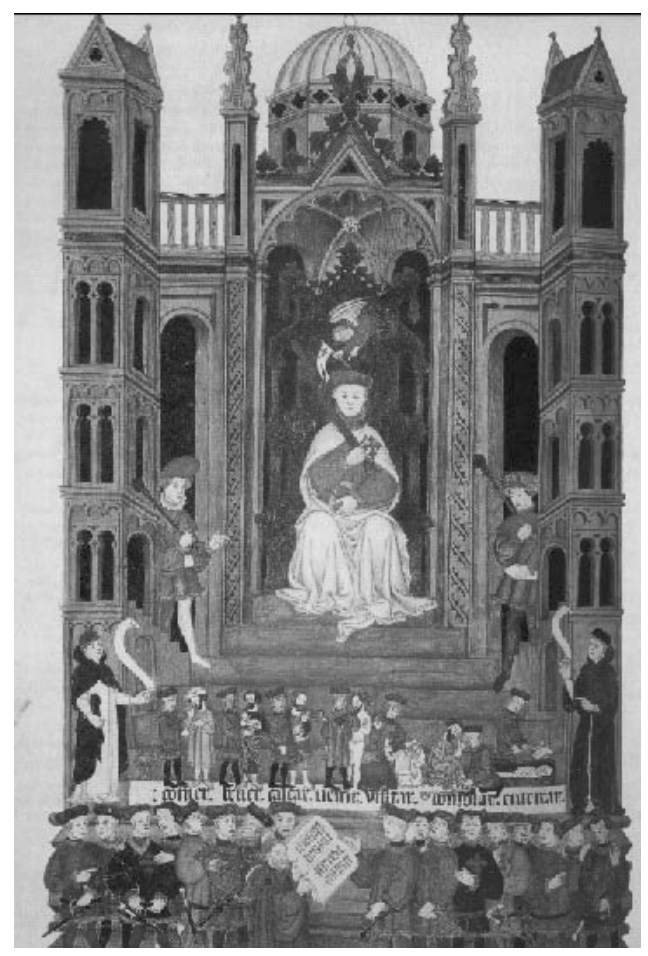

Figura 12. Presentación a Luis González de Guzmán de la Biblia traducida por Moisés Arragel. Biblia de Alba. ca. 1430 (Madrid, Palacio de Liria, ms. 399, fol. 25 v.). 